\title{
Article \\ Technical and Economic Analysis of Modernization of Solar Power Plant: A Case Study from the Republic of Cuba
}

\author{
Emiliia Iakovleva ${ }^{1, *(\mathbb{D})}$, Daniel Guerra ${ }^{1}$, Pavel Tcvetkov ${ }^{2, *(\mathbb{D}}$ and Yaroslav Shklyarskiy ${ }^{1}$ \\ 1 General Electrical Engineering Department, Saint Petersburg Mining University, 2, 21st Line, \\ 199106 St. Petersburg, Russia; dgd210386@gmail.com (D.G.); Shklyarskiy_YaE@pers.spmi.ru (Y.S.) \\ 2 Department of Economics, Organization and Management, Saint Petersburg Mining University, 2, 21st Line, \\ 199106 St. Petersburg, Russia \\ * Correspondence: yakovleva_ev@pers.spmi.ru (E.I.); pscvetkov@yandex.ru (P.T.); Tel.: +7-921-375-4619 (E.I.)
}

\section{check for}

updates

Citation: Iakovleva, E.; Guerra, D.; Tcvetkov, P.; Shklyarskiy, Y. Technical and Economic Analysis of Modernization of Solar Power Plant: A Case Study from the Republic of Cuba. Sustainability 2022, 14, 822. https://doi.org/10.3390/ su14020822

Academic Editors: Giuliano Poli, Daniele Cannatella and Sabrina Sposito

Received: 19 November 2021

Accepted: 7 January 2022

Published: 12 January 2022

Publisher's Note: MDPI stays neutral with regard to jurisdictional claims in published maps and institutional affiliations.

Copyright: () 2022 by the authors Licensee MDPI, Basel, Switzerland. This article is an open access article distributed under the terms and conditions of the Creative Commons Attribution (CC BY) license (https:// creativecommons.org/licenses/by/ $4.0 /)$.

\begin{abstract}
The problem of increasing the efficiency of existing power plants is relevant for many countries. Solar power plants built at the end of the 20th century require, as their shelf lives have now expired, not only the replacement of the solar modules, but also the modernization of their component composition. This is due to the requirements to improve the efficiency of power plants to ensure the expansion of renewable energy technologies. This article presents a technical and economic analysis of the choice of solar power plant modernization method, which consists of (1) a method for calculating the amount of power generation; (2) the modeling of solar power plants under specific climatic conditions; (3) the analysis of electricity generation using different types of PV modules and solar radiation trapping technologies in Matlab/Simulink; and (4) the technical and economic analysis of a $2.5 \mathrm{MW}$ solar power plant in the Republic of Cuba (in operation since 2015), for which four different modernization options were considered. All the scenarios differ in the depth of modernization; the results of the analysis were compared with the existing plant. The results of the study showed that the different modernization scenarios respond differently to changes in the inputted technical and economic parameters (cost per $\mathrm{kWh}$, inflation rate, losses, and power plant efficiency). The maximum NPV deviations among the considered scenarios are: a $1 \%$ increase in inflation reduces NPV by $2 \%$; a decrease in losses from $20 \%$ to $10 \%$ increases the NPV by $2.5 \%$; a change in cost from EUR 0.05 to EUR 0.1 increases the NPV by more than 3.5 times. The dependence of the economic results was also tested as a function of three factors: solar module efficiency, inflation, and the price per $1 \mathrm{kWh}$. It was found that the greatest influence on the NPV of the proposed model is the price per $1 \mathrm{kWh}$. Based on this analysis, an algorithm was developed to choose the most effective scenario for the conditions of the Republic of Cuba for the modernization of the existing power plants.
\end{abstract}

Keywords: solar power plant; renewable energy; modernization; technical-economic assessment; photovoltaic repowering; Republic of Cuba

\section{Introduction}

Today, the share of renewable energy sources in the global energy sector has a steady growth trend, despite several obstacles [1]. Renewable sources primarily include solar and wind energy [2-4], tidal energy [5], geothermal energy [6], and biogas [7,8].

Renewable energy sources using modern technological solutions meet all the requirements that are imposed on energy sources today-maneuverability [9], availability, continuity [10], the ability to forecast [11], and planning [12,13].

One of the main advantages of renewable energy sources is the environmental friendliness of the electricity generation. Of course, the production of components for renewable energy power plants, such as wind turbines, solar modules, batteries [14], and converter and switching equipment [15], requires significant costs to allow the reuse of resources 
during production and disposal (passive phase) [16]. Moreover, according to recent studies, special attention should be paid to the distribution planning of solar power plants in countries that occupy significant areas as $\mathrm{CO}_{2}$ emissions may increase $[17,18]$. However, the life cycle of the above equipment is much longer; it exceeds the total time spent on production and disposal, and the reduction in the negative environmental impact in the active phase of use prevails over the negative passive phase.

The exponential growth in the share of renewable energy sources began at the end of the 20th century. According to the lifespan of the component composition of the power plants, many of them today require modernization and reconstruction. Several researchers are engaged in improving the efficiency of solar power plants, searching for the optimal component composition. For example, Veysel Çoban [19] presents the results of a study on the applicability of Fuzzy Logic methods and the Analytic Hierarchy Process in the selection of a solar power plant. The introduction of linguistic terms used by experts helps to map knowledge and experience more clearly when evaluating the choice of a solar power plant. However, it should be noted that this approach was only applied to certain climatic and geographical conditions and evaluated by experts from one country. For other countries and conditions, the results may differ. A group of scientists led by Kiene $S$. developed a way to modernize a hydroelectric power plant. The essence of modernization is to change the structure of the power plant and add a pumped-storage hydropower plant to its structural scheme. The authors have developed an algorithm for calculating the modes of operation of a pumped-storage hydropower plant (PSHP) [20]. In [21], the genetic algorithm is applied to optimize the course of a civil construction of a hydropower plant. The results of the study showed that the genetic algorithm has a positive effect on reducing construction costs and improving the quality of the project. In [22], various types of power equipment modernization are also considered in terms of economic efficiency. To assess the effectiveness of solar and wind energy for power generation, a group of Spanish scientists developed a virtual power plant, simulating the modes of operation when changing its structure, allowing changes to the technical and economic models, and selecting the most profitable power production [23].

One of the general trends in the field of increasing the efficiency of solar power plants and the algorithms for selecting their composition is the method of tracking the maximum power point [24]. There are also a large number of works aimed at determining the optimal location of a solar power plant $[25,26]$. Particular attention in the field of solar power is paid to algorithms for controlling solar tracking systems, which are known to increase the efficiency of solar ray trapping [27]. This paper presents a developed algorithm for selecting the type of modernization of a solar power substation; it is based on the formed function of the dependence of the energy generated by the substation on the given constraints. The results proving the positive impact of the use of solar energy in the Republic of Cuba on the environmental situation, namely the reduction in carbon dioxide emissions into the atmosphere, are also presented. The algorithm was developed with the account of the economic assessment of various options for generating electricity using solar panels with solar tracking systems and with stationary systems, identifying the factors limiting modernization and determining the dependence of the modernization method on the economic resources of the region. For this purpose, it was decided to use the present value of the equipment to calculate the initial cost. The investment was defined as all the economic components necessary to carry out the modernization of the solar generators at the Santiago de Cuba solar station.

Today, there are various software products for selecting solar power plant components (PVWatts and System Advisor Model (SAM)). PVWatts can calculate the energy produced by a photovoltaic plant and the monthly and annual radiation. The System Advisor Model can calculate the output of a solar power plant based on several mathematical models. SAM allows the calculation of the performance of solar power plants in order to determine the costs of the electricity generation with the design and operating costs. This program takes into account various climatic factors and weather changes. The LCOE is a tool that allows 
you to analyze different power generation projects of different sizes and technologies and bring them to a single unit of comparison. The LCOE calculation model is a very effective method for determining the cost of each $1 \mathrm{kWh}$, produced not only by solar plants but also by other renewable energy systems [28]. However, this methodology involves selecting the optimal installation site for a new photovoltaic power plant and does not apply to a power plant that is already in operation.

In [29], the algorithm based on the fuzzy analytical hierarchical process model (FAHP) and data envelopment analysis (DEA) is described for solar panel supplier selection during the design process. The results of this work can be used to select a solar panel supplier but do not address the other components of the solar power plant. The study [30] considers the modernization of the power supply system of the seaport in Kaliningrad as part of a zeroemission strategy [31]. Considering various options for implementing RESs in the power supply system of the seaport, the authors conclude that a significant increase in efficiency is possible through the use of distributed generation schemes and modern equipment, such as transformers, but the justification of these solutions requires the development of comprehensive mathematical models with optimization algorithms. The work does not present algorithms for selecting the structure of the system with RESs; rather, it presents only modified aspects that need to be taken into account when modernizing the entire power supply system of a sea terminal. The work [32] considers the methodology and criteria for evaluating solar energy compared to other types of RESs for an autonomous consumer. The sustainability index as an indicator of the agglomeration function is used to rank electric energy sources.

The analysis of the studies and technologies presented above showed that, firstly, there are currently no algorithms for the modernization of solar power plants in the climatic, technological, and economic conditions of the Republic of Cuba or countries with similar climatic and economic conditions. Secondly, the existing algorithms are mainly designed to choose the modernization of hydroelectric power plants or to consider finding the best choice between different types of renewable energy resources or to choose the most efficient type of RESs in an autonomous system or one connected to the centralized power supply network or to choose the optimal supplier of solar power plant components. This study only considers the option of using solar energy and modernizing the existing power plant. Today, many solar power plants have already been built, and the installation sites and the principle of operation (photovoltaic or photothermal) have already been determined; so, changing the source of renewable energy is out of the question. Modernization opportunities lie only in finding the optimal composition of the power plant corresponding to the level of the technical development of the technology and the economic opportunities of the company in particular or the state as a whole. Thirdly, subsidies and incentives play an important role in all technical and economic calculations. In the context of the Republic of Cuba, these economic aspects do not play a role today. Furthermore, in conclusion, this paper uses the results of the simulation of power generation in the different types of modernization of the directly studied object; the results take into account all the peculiarities of the climatic parameters of the region.

This article examines the modernization of a direct-conversion solar power plant to find the most effective way to ensure the second life of the power generation facilities. It is based on a previously performed analysis of the renewable energy potential of the Republic of Cuba [33,34]. It also presents statistical data from the CIES weather station, collected by the authors (Appendix A). It should be noted that the data were taken for the years 2010-2020; the appendix shows the minimum, maximum, and average values for each month of parameters - the solar radiation during the day, the ambient temperature, the relative humidity*, and the wind speed* (*at $2 \mathrm{~m}$ above the ground). To test our model, we considered a case study-a $2.5 \mathrm{MW}$ solar power plant located in the Republic of Cuba. The choice was justified by five factors: the need to increase the energy supplied to the national grid; the need to modernize the power plant due to the expiration date of the solar modules; the low efficiency of the power plant, which is currently lower than 
that stated in the design; the huge potential of solar energy in Cuba; and the developing economy of the country, which imposes restrictions on modernization due to strictly limited investment. The proposed approach could be scaled up to the entire solar power industry of the Republic of Cuba, which is the key contribution of this study.

The rest of the paper is organized as follows. Section 2 presents an analysis of the Cuban energy industry, describing the object of the study, the photovoltaic plant Santiago de Cuba, and the stages of the technical and economic analysis, based on which four scenarios for the modernization of the solar power plant were chosen. Section 3 presents the results of the study, namely the dependence of the NPV on inflation, losses, and the cost of modernization. Based on these results, an algorithm for selecting the type of modernization is presented. Section 4 presents the conclusions of the paper.

\section{Materials and Methods}

\subsection{Renewable Energy in the Republic of Cuba: State of the Art}

According to data provided by the Electric Power Company of the Republic of Cuba in its annual report, the country generated 22,000 GWh of power in 2018, of which $94 \%$ came from traditional energy sources. The remaining $6 \%$ came from renewable energy sources (Figure 1).
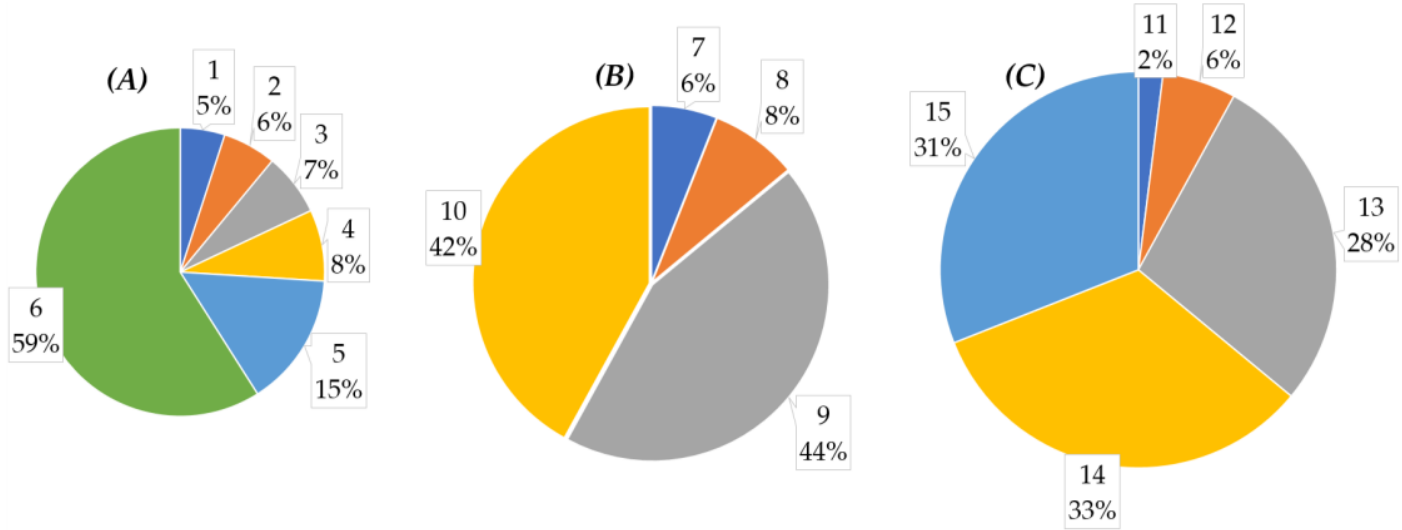

Figure 1. (A) Structure of energy generation in 2018-2020: (1) diesel fuel; (2) renewable energy sources; (3) other; (4) natural gas; (5) fuel oil; and (6) thermal power plants. (B) Structure of fuel consumption: (7) diesel fuel; (8) fuel gas; (9) fossil fuels; (10) fuel oil. (C) Distribution of green power plant by types, according to the energy development strategy of Cuba: (11) hydro; (12) other; (13) wind; (14) bio; (15) solar [34,35].

The annual consumption of fuel oil in the country is about 6 million tons, and $42 \%$ of it is used for electricity generation in thermal power plants. The rest is mainly used in combustion processes in the furnaces and boilers of sugar, chemicals, and nickel and in the paper and cardboard, metallurgical, and cement industries, as well as in the merchant maritime transport [36]. As a result, the combustion of such a quantity of hydrocarbon fuel harms the environmental situation (especially $\mathrm{CO}_{2}$ emissions $[37,38]$ ) in the country, especially considering the obsolete technological equipment used in the industry [39].

There are various causes photovoltaic module degradation: the potential-induced degradation (PID) phenomenon [40], electromigration and delamination, electrical insulation failure, discoloration, and corrosion [41]. It should also be noted that the causes of degradation can be external factors-climatic conditions, improper transportation, circuit solutions of the system as a whole, etc. Given the complexity of the issue, in this study the degradation effect of solar panels was not considered in detail.

The Republic of Cuba has a plan for the development of renewable energy until 2030. It is planned to introduce power plants based on renewable energy sources with a total installed capacity of 2269 MW. Figure 1C shows the percentage distribution of the power plants. As can be seen from the percentage distribution, the share of the capacity of solar 
power plants is almost one third of the total capacity, so the feasibility of modernization is obvious. If we take into account the modernization of the already existing solar power plants (there are 40 solar power plants in Cuba today), we can expect that the electricity generated by RESs will account for more than $24 \%$ of the total electricity generated in Cuba.

Studies by a team of scientists led by López-González A. have proven that the transition from traditional fuels to solar power plants is effective in improving the environmental situation in Cuba but requires increasing the energy capacity of the solar modules and strengthening the socio-economic and technical aspects [42].

For this purpose, it is necessary to conduct a study of the radiation regime over time, followed by the generation of heat or electricity for the month/season/year, with an additional assessment of the technical and economic indicators. Data from global satellite systems and climate atlases, as well as field measurements, can be used to analyze the insolation. The amount of solar radiation depends on the latitude and varies from $6.5 \mathrm{kWh} / \mathrm{m}^{2}$ at the equator to $4 \mathrm{kWh} / \mathrm{m}^{2}$ at the pole.

In some regions of the Republic of Cuba, the average amount of solar radiation falling on a horizontal surface (per $1 \mathrm{~m}^{2}$ ) can be $5 \mathrm{kWh} / \mathrm{m}^{2}$ (see Figure 2). The figure shows the solar radiation intensity using SUNY modeling tools, a program that has a high spatial resolution $(1 \times 1 \mathrm{~km})$ and operates based on satellite images. The figures in Appendix $A$ show the average solar radiation values obtained in 2010-2020.

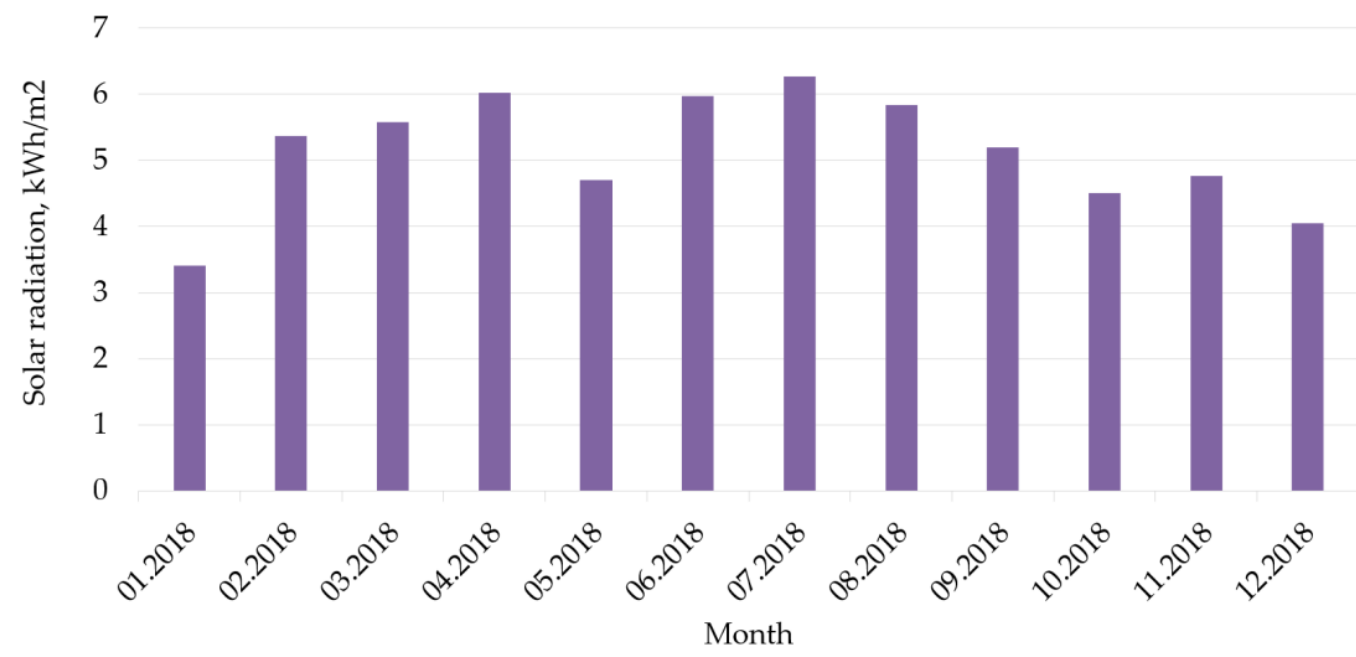

Figure 2. Solar potential in the Republic of Cuba.

The solar radiation data used in this work cover one year, from 1 January 2018 to 31 December 2018 (Figure 2).

Table 1 shows the installed capacity (in electrical power) of the renewable energy plants operating in the Republic of Cuba. The government plans to increase the share of renewable energy in the national energy balance from $6 \%$ to $24 \%$ by 2030 .

Table 1. Summary of Renewable Energy Generated in Cuba (in 2020). Based on [37].

\begin{tabular}{cc}
\hline Renewable Energy & Capacity \\
\hline Bioelectric power stations & $469.2 \mathrm{MW}$ \\
Photovoltaic stations & $159 \mathrm{MW}$ \\
Wind turbines & $11.5 \mathrm{MW}$ \\
Small hydropower plants & $68.3 \mathrm{MW}$ \\
\hline
\end{tabular}

\subsection{Santiago de Cuba Solar Power Plant}

In the Republic of Cuba, 22 solar power plants (PVs) with a total capacity of $37 \mathrm{MW}$ were brought into the country's energy supply system between 2014 and 2017 in 10 provinces (Figure 3A). However, many of these photovoltaic plants (PVs) are not achieving the ex- 
pected levels of power production as declared in the design. The main reason for this discrepancy between the design data and actual data is the low efficiency of the components that make up power plants. Studies carried out on a 2.5 MW PV substation (Figure 3B) in the eastern province of Santiago de Cuba showed that the main reason for the low efficiency lies in the PV generators themselves. Thus, there are at least 16 solar power plants requiring modernization aimed at increasing the efficiency of the electricity generation.

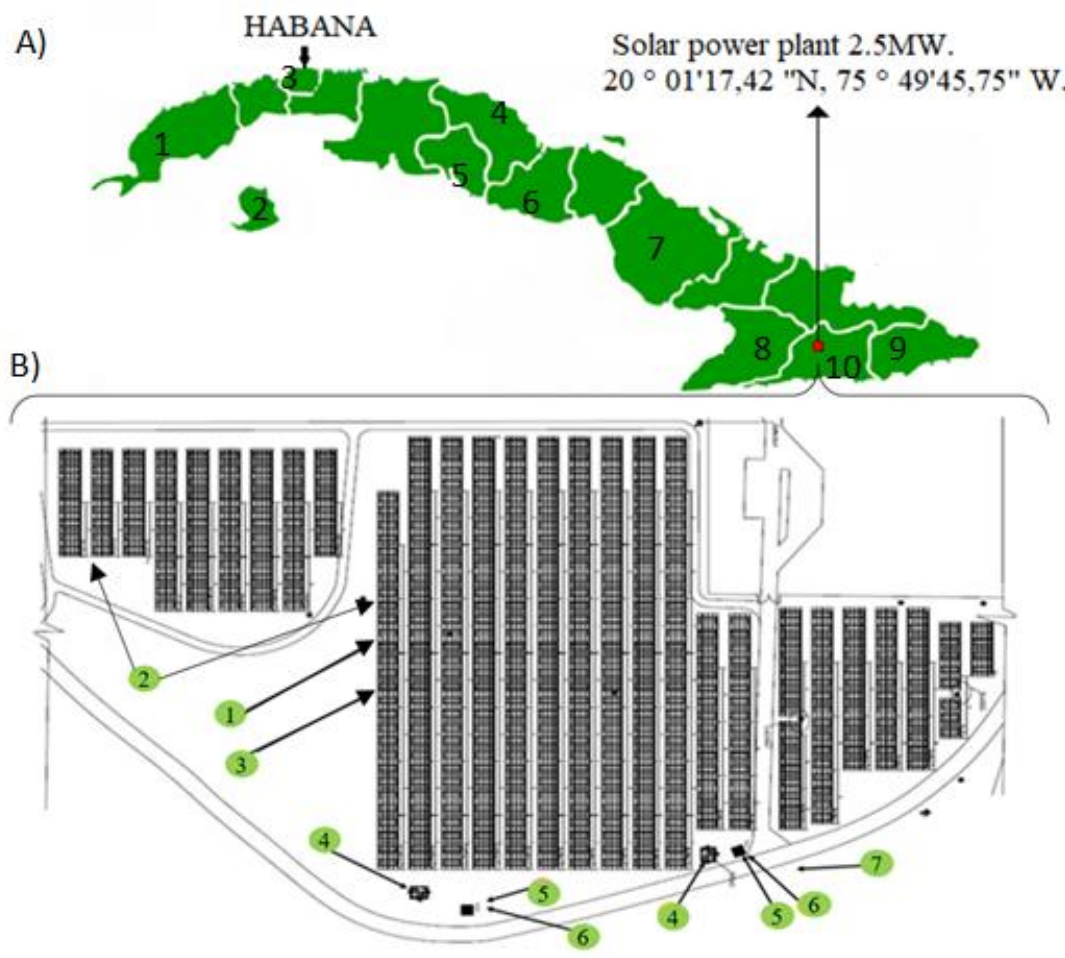

Figure 3. Solar power plants in the Republic of Cuba established in 2014-2017. (A): 1-Pinar del Rio 4.3 Mw; 2-Isla de la juventud 4.2 Mw; 3-Habana $2 \mathrm{Mw}$; 4-Villa Clara $1 \mathrm{Mw}$; 5-Cienfuegos 11.4 Mw; 6-Sancti Spiritus 1.3 Mw; 7-Camaguey 2.8 Mw; 8-Granma 2.4 Mw; 9-Guantanamo $5.1 \mathrm{Mw}$; 10 -Santiago de Cuba 2.5 Mw. (B): 1—solar generator (brand NUM SOLAR, model DCM240-C); 2-panels of electrical connections between the generator and the inverter (PC); 3-threephase inverters (Brand: SUNNY TRIPOWER, Model 17000TL); 4-general distribution panel (PGD); 5-three-phase transformers; 6-reduction main substation (PPR). 7-a power grid $13.8 \mathrm{kV}$.

The 2.5 MW solar power plant has 10,320 (240 Wp) solar panels with a nominal power deviation of $\pm 3 \%$ and, according to the Solar Energy Research Center study, the average solar power deviation is $8 \%$. This means that the real capacity of the solar generator at the 2.5 MW solar power plant in Santiago de Cuba is limited to $2.3 \mathrm{MW}$, which is about $20 \mathrm{~kW}$ less, due to this problem. Figure 4 shows a simplified schematic diagram of the solar power plant in question, with a brief specification of the key components.

As indicated, the greatest efficiency problems arise in the solar generator of the solar power plant because the other system components, such as the three-phase inverters and the transformers, meet the necessary technical requirements. 


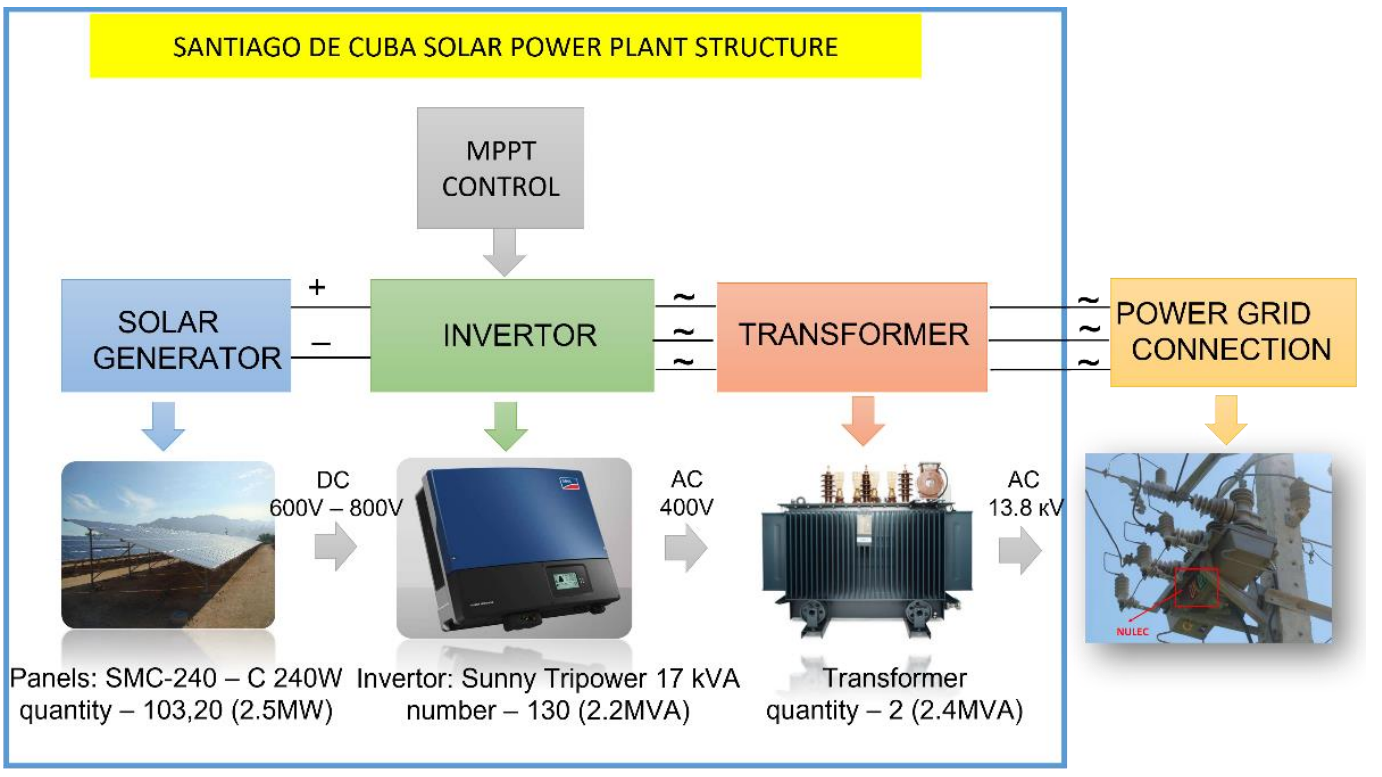

Figure 4. Schematic diagram of the power plant under study.

\subsection{Technical Analysis for the Choice of the Modernization Scenario}

The study did not set the task of changing the type of RES; the modernization options were considered only within the framework of solar energy application. Moreover, only the photovoltaic method of converting solar energy into electrical energy was considered. To select the type of modernization relative to the already existing structure (Scenario 0 ), the following were carried out:

1. Analysis of the climatic variables of the Santiago de Cuba region, identifying the parameters that contribute most to the generation of electrical energy.

2. Development of a mathematical and computer model of the solar power plant in MATLAB Simulink software according to Scenario 0 , taking into account the identified climate variables, followed by a simulation of the solar power plant's electricity generation.

3. Technical analysis of different solar tracking systems.

4. Making changes to the structure of the solar power plant model (application of the sun tracking system) and conducting simulation.

5. Technical analysis of commercially available photovoltaic modules, transformers, and inverters, taking into account the possibility of purchasing a particular component in Cuba.

6. Determination of the optimal model of a solar module and calculation of the required number of panels, as well as determination of the method of their installation.

7. Selection of modernization scenarios.

Further in this section, the above steps are considered.

In previous studies, the most efficient way to calculate the electricity generated by a solar power plant was determined. A correlation analysis was performed [43]. The results of the study showed that the correlation between the operating temperature of the photovoltaic panel and the relative humidity, wind speed, and pressure is at a low level (Table 2). The methodology for calculating the generated energy is to take into account different climatic characteristics, the optimal number of which for Cuba is two indicators, namely temperature and solar radiation.

After determining the method of calculating electricity, the values of the generated energy for the stationary installation of the photovoltaic modules and for the use of the solar tracking system were obtained. Based on mathematical and computer modeling and experimental studies, it was confirmed that the most efficient way is the installation of 
solar tracking systems [44]. Figure 5 shows the structure of the method for calculating the generated solar energy of a solar power plant.

Table 2. The value of the correlation of energy and climatic parameters (2018) [44].

\begin{tabular}{cccccc}
\hline Parameter & $\begin{array}{c}\text { Ambient } \\
\text { Temperature }\end{array}$ & $\begin{array}{c}\text { Solar } \\
\text { Irradiation }\end{array}$ & $\begin{array}{c}\text { Relative } \\
\text { Humidity }\end{array}$ & $\begin{array}{c}\text { Atmosphere } \\
\text { Pressure }\end{array}$ & Wind Speed \\
\hline Energy & 0.75 & 0.70 & -0.73 & -0.13 & 0.55 \\
\hline
\end{tabular}

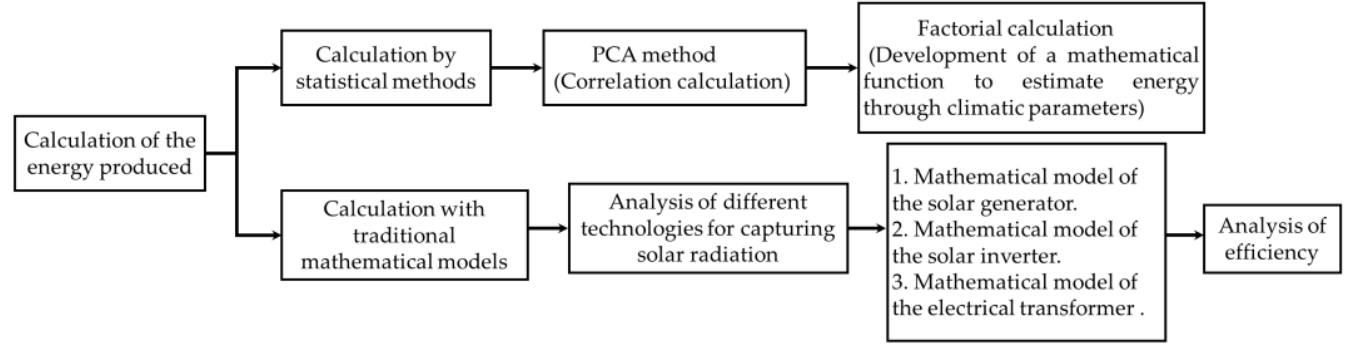

Figure 5. Method of calculating the energy of the solar power plant.

After analyzing all the components of the system (solar generator, electric inverters, and electric transformer), the problems of low efficiency and significant losses of energy produced by the solar power plant were identified. It was found that the biggest efficiency problems and, therefore, production energy losses in the $2.5 \mathrm{MW}$ plant were in the solar panels. For this reason, a techno-economic analysis of the possible indicators of system modernization was carried out.

Currently, the $2.5 \mathrm{MW}$ solar power plant in the province of Santiago de Cuba consists of the 10,400 solar panels of which the solar generator is composed, each of which has a power of $240 \mathrm{~W}$ with an efficiency of 16\% (DSM-240-C).

To fulfill the task of the study, a sample of 10 different solar modules with the highest efficiency, which can be used to replace the current solar module DSM-240-C, was determined. Table 3 shows the main parameters as well as the cost of the solar panels.

Table 3. Selection of solar modules for the design of a new solar generator at a $2.5 \mathrm{MW}$ power plant.

\begin{tabular}{|c|c|c|c|c|c|c|c|}
\hline № & Model & Power, W & Efficiency, \% & Technology & Cost, EUR/W & Panel Cost & Producing Country \\
\hline 1 & SKT375M6-20/AB & 320 & 19.7 & Monoc & 0.195 & 62.4 & China \\
\hline 2 & HCM60X9-345W & 345 & 20.4 & Monoc & 0.2 & 69 & Spain \\
\hline 3 & MS400PM5-66SA & 400 & 21.3 & PERC & 0.198 & 79.2 & USA \\
\hline 4 & AE M6-60 320W & 320 & 19.24 & PERC & 0.185 & 59.2 & Germany \\
\hline 5 & UZ158MHC340-60 & 340 & 20.1 & Monoc & 0.159 & 54.06 & China \\
\hline 6 & SR-325-340-120M & 340 & 20 & Monoc & 0.181 & 61.54 & Germany \\
\hline 7 & EX340M-120 & 340 & 20.1 & Monoc & 0.198 & 67.32 & Spain \\
\hline 8 & ASP345P6-72 & 345 & 17.8 & Polic & 0.176 & 60.72 & Germany \\
\hline 9 & NS-290P6 & 290 & 17.8 & Polic & 0.152 & 44.8 & China \\
\hline 10 & SP360-120M & 360 & 19.46 & PERC & 0.190 & 68.4 & China \\
\hline
\end{tabular}

Based on the calculations (Figure 6), the solar module of the production model UZ158MHC340-60, with a capacity of $2.5 \mathrm{MW}$, will be selected for the modernization of the static generator of the power plant as it offers a better cost/energy ratio than other modules. The calculation of the amount of electricity for the climatic conditions of the Republic of Cuba, obtained from photovoltaic panels, is made according to expression 1.

$$
E_{r}=P_{p v} * H S * 0.9
$$

where $E_{r}$ is the real energy supplied by the solar panel $(\mathrm{kWh}) ; f_{p v}-$ is the panel efficiency $(\%) ; P_{p v}$ is the panel rated power $(\mathrm{W})$; and $H S$ are the hours of sunshine per month [45]. 


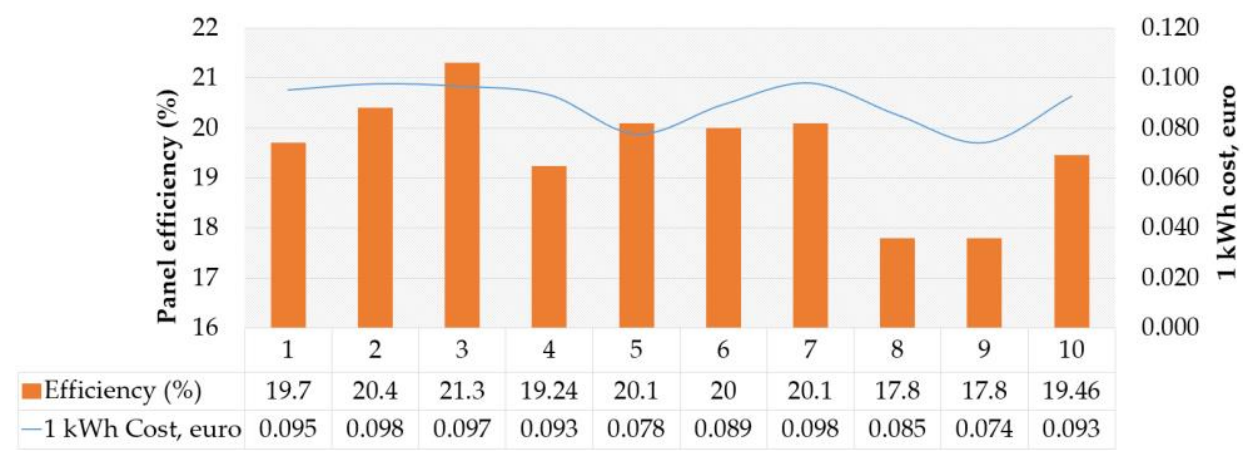

Figure 6. Ratio of the cost (EUR/kWh) of production and efficiency of different models of solar panels.

Then the solar panel with the highest power generation and lowest cost was selected.

In addition to improving the generator structure [46], which consists in increasing the efficiency of the panels, the second positive factor is the reduction in the number of modules themselves. In total, 3046 fewer solar modules will be used, making 7354 units. This number of modules will be enough to provide the same amount of energy generated per year. This proves that the replacement of the old solar modules with an efficiency of $16 \%$ with modules with the higher efficiency of $20.1 \%$ is advisable.

After determining the model and the number of solar modules needed, the required distance for each group of metal supports on which the solar panels will be installed is determined [47]. This is necessary to increase the effect of shading and dust. According to the calculations obtained based on expression 2, the minimum distance at which the generators should be located is $2.8 \mathrm{~m}$; currently, the generators are located at a distance of about $2 \mathrm{~m}$.

$$
\begin{gathered}
H=L * \operatorname{sen}(\beta) \\
\mathrm{D}=\frac{H}{\tan (61-\varphi)}
\end{gathered}
$$

where $D$ is the distance between photovoltaic panels $(\mathrm{m}) ; H$ is the photovoltaic panel height $(\mathrm{m}) ; \beta$ is the tilt angle of the south-facing photovoltaic panels (degrees); and $\varphi$ is the latitude of the location of the photovoltaic system.

As mentioned earlier, the studies described in previous papers allowed us to identify the modernization options that provide the maximum energy gain [44]. The performance of the solar tracking systems in the Santiago de Cuba area is satisfactory and allows an increase in the amount of energy supplied to the national power grid provided by solar tracking systems compared to that of the stationary systems (Table 4).

Table 4. Percentage increase in energy supplied by solar tracking systems compared to stationary systems in the specific climatic conditions of the Republic of Cuba.

\begin{tabular}{lccccccccccccc}
\hline Months & $\mathbf{1}$ & $\mathbf{2}$ & $\mathbf{3}$ & $\mathbf{4}$ & $\mathbf{5}$ & $\mathbf{6}$ & $\mathbf{7}$ & $\mathbf{8}$ & $\mathbf{9}$ & $\mathbf{1 0}$ & $\mathbf{1 1}$ & $\mathbf{1 2}$ & Overall Average \\
\hline E (\%) & 26 & 21 & 28 & 35 & 32 & 40 & 40 & 43 & 31 & 30 & 24 & 22 & 31 \\
\hline
\end{tabular}

\subsection{Scenario Description}

Thus, based on the research, 5 different scenarios of the power plant modernization were selected to assess the economic consequences necessary for the development of the algorithm.

0 S0: Solar power plant without modernization

1. S1: Modernization of a $2.5 \mathrm{MW}$ stationary solar power plant with preservation of inverters, transformers, and other system components

2. S2: Installation of a tracking system with the model of current photovoltaic modules (DSM-240-C) 
3. S3: Modernization of the solar generator with a solar energy monitoring system of a 2.5 MW solar power plant, taking into account other system components (inverters, transformers, and others)

4. S4: Modernization of the solar generator with a solar energy monitoring system of a 2.5 MW solar power plant with the preservation of inverters, transformers, and other system components

The first, second, and third scenarios are justified by the developed computer model [44]. The fourth scenario is explained by the maximum possible replacement in the structure of the power plant and assuming the largest increase in capacity.

\subsection{Economic Analysis}

Figure 7 shows the flowchart of economic evaluation that was conducted in this study.

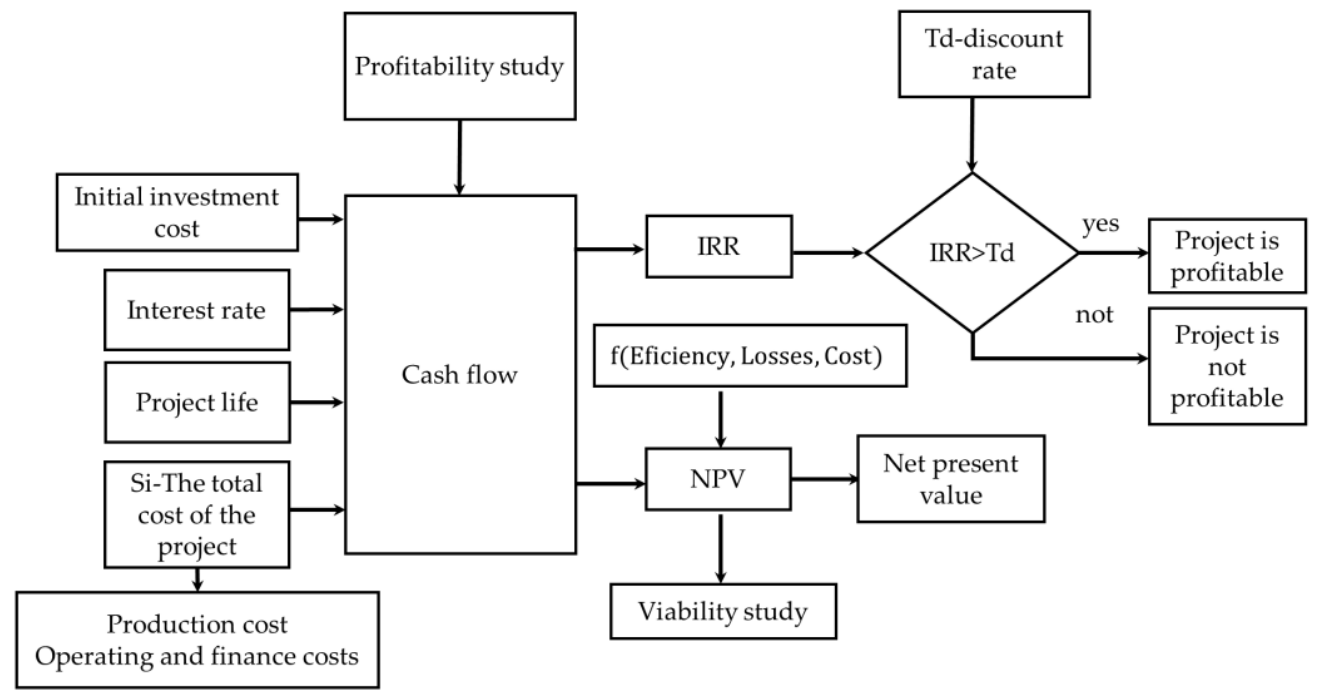

Figure 7. Flowchart of economic evaluation.

In all the investments related to photovoltaic systems, the bulk of the investments is for the purchase and installation of solar panels; this parameter is characterized by the greatest economic effect from investments in solar systems. The required initial costs are presented in Table 5.

The service life of the solar modules is 25 years (25-30 on average, according to technical documentation from the producers). The operating costs are low because the solar modules operate autonomously and require only periodic removal of dirt and dust from the surface from time to time. The frequency of surface cleaning depends on the location of the modules (trees and grass) and the angle of their slope [49]. The operation and maintenance costs of the photovoltaic power generation systems are low, ranging from $0.5 \%$ to $1.5 \%$ per annum of the initial investment cost [50]. Wages are calculated using the average wage for the industry and taking into account regional wage changes. The industry wage for a staff of 4 is EUR 5059 per year (according to the documents of the Santiago de Cuba solar power plant).

For further calculation, it is necessary to determine the rates that are subject to inflation each year. The inflation rate is the percentage by which the price level of goods and services changes or is expected to change annually; in this case, it is $5 \%$.

The discount rate determines the present value of future cash flows. The Central Bank of Cuba sets it at $12 \%$ for projects with a return of capital within 4 years, under Decree No. 289, Article 5 (November 2011). 
Table 5. Operational and maintenance costs. Based on data from [48].

\begin{tabular}{cc}
\hline Operating Costs & Cost (EUR) \\
\hline Solar Modules (S1) & 504,300 \\
Solar Modules and Sun Tracking System (S2) & 902,300 \\
Inverter & 91,700 \\
Electrical transformers & 32,107 \\
Complex installation with sun tracking system (S3) & $1,026,107$ \\
Installation and transportation & 324,730 \\
Device maintenance (S0) & 0 \\
Device Maintenance (S1) & 2521 \\
Device Maintenance (S2) & 10,000 \\
Device Maintenance (S3) & 13,535 \\
Device Maintenance (S4) & 22,499 \\
Other costs & - \\
Total price (S0): & 0 \\
Total price (S1) & 831,551 \\
Total price (S2) & $1,237,030$ \\
Total price (S3): & $1,744,865$ \\
Total price (S4): & $1,877,636$ \\
\hline
\end{tabular}

The discount rate is calculated using the following formula:

$$
r_{C A P M}=r_{f}+\rho *\left(r_{m}-r_{f}\right)
$$

where $r_{f}$ is the risk-free rate that is determined from the current yield on Cuban government bonds; $r_{m}$ is the expected market return, i.e., the return that the investor expects to receive from the stock market performance; and $\rho$ is used to mathematically describe the relationship between movements of individual stocks in relation to the entire market.

As this paper deals with the modernization of a solar power plant in the region of Santiago de Cuba, the bank interest rate is expected to be $6.5 \%$. This is due to the fact that the increase in the generated energy is beneficial not only for the investors but also for the municipality. Therefore, the administration can facilitate a loan at a reduced rate. Cuba has two laws regulating renewable energy and foreign investments, DL 345/2018 and DL $118 / 2014$. Due to the fact that Cuba is a socialist country, the policy of subsidizing electricity production is only now beginning to develop. To date, there has only been a change in the tariffs for the sale of electricity [51]. In addition, there is no difference in the selling price of electricity from different types of power plants, whether using fossil fuel or renewable energy sources. However, there is a difference in cost per kWh for Cuban and foreign producers, for whom the cost and taxes are regulated by separate contracts with Unión Eléctrica (UNE). The income from modernization is calculated at the minimum project price, and the projected growth according to the expression in [50] amounts to

$$
C_{\text {in }}=C_{\text {min }} * W * \sum_{n=1}^{T}\left(1+r_{i}\right)^{n}
$$

where $C_{\min }$ is the minimum electricity price (USD $0.10 / \mathrm{kWh}$ ); $W$ is the generated electricity $(\mathrm{kW})$; and $r_{i}$ is the growth rate (\%).

According to the decree (Resolution No. 435/2017) of the Ministry of Energy and Mines of the Republic of Cuba, the cost of $1 \mathrm{kWh}$ of photovoltaic energy was USD $0.10 / \mathrm{kWh}$ in 2018 [52]. On the other hand, according to the Economic Commission for Latin America and the Caribbean (EPAL), economic growth in the Republic of Cuba will increase by $2.2 \%$ by 2021.

To analyze the key financial indicators of the project, the net present value (NPV) was used [53]. To calculate the NPV of the net cash flows and to discount the cash flows 
generated during the project, the lifetime of the project is set equal to 25 years as the average service life of the main equipment in the system (solar panels, inverter, etc.) is the same:

$$
\mathrm{ROI}=\frac{\mathrm{NPV}}{\mathrm{C}_{o}}=\frac{1}{\mathrm{C}_{o}} \cdot \sum_{n=1}^{T} \frac{\mathrm{CF}}{(1+r)^{T}}
$$

where $C_{o}$ is the amount of initial investments and $C F$ (cash flow) is a quantitative expression of the money at the disposal of the organization; for the managers and owners of the company, it is the planned cash flow of the company over time or a summary of the data on its flow in previous periods, and for the investor, $C F$ is the expected future income from investments (taking into account the discount) [54].

In this paper, we investigated three types of NPV dependencies as a function of 4 parameters-inflation rate, power plant efficiency, power losses, and cost per $\mathrm{kWh}$ :

$$
\mathrm{NPV}=f(\text { inf } ; \text { efficiency;losses, cost })
$$

The base models are 4 scenarios of modernization with an inflation rate of $5 \%$, efficiency of $80 \%$, losses of $20 \%$, and the cost of EUR 0.08 per $1 \mathrm{kWh}$ (the cost set by the Cuban government). The efficiency of solar modules is $21.1 \%$.

Based on the models developed by Matlab/Simulink, using the RetScreen software product, different variations of the input parameters were analyzed.

\section{Results and Discussion}

\subsection{Technical and Economic Analysis}

First of all, the work investigated the effect of the inflation rate on the NPV. It was found that an increase in the level of inflation has a negative impact on the NPV regardless of the type of modernization. It was also found that all of them are sensitive to changes in the level of inflation (Figure 8). An increase in inflation by $1 \%$ reduces the NPV by $2 \%$.

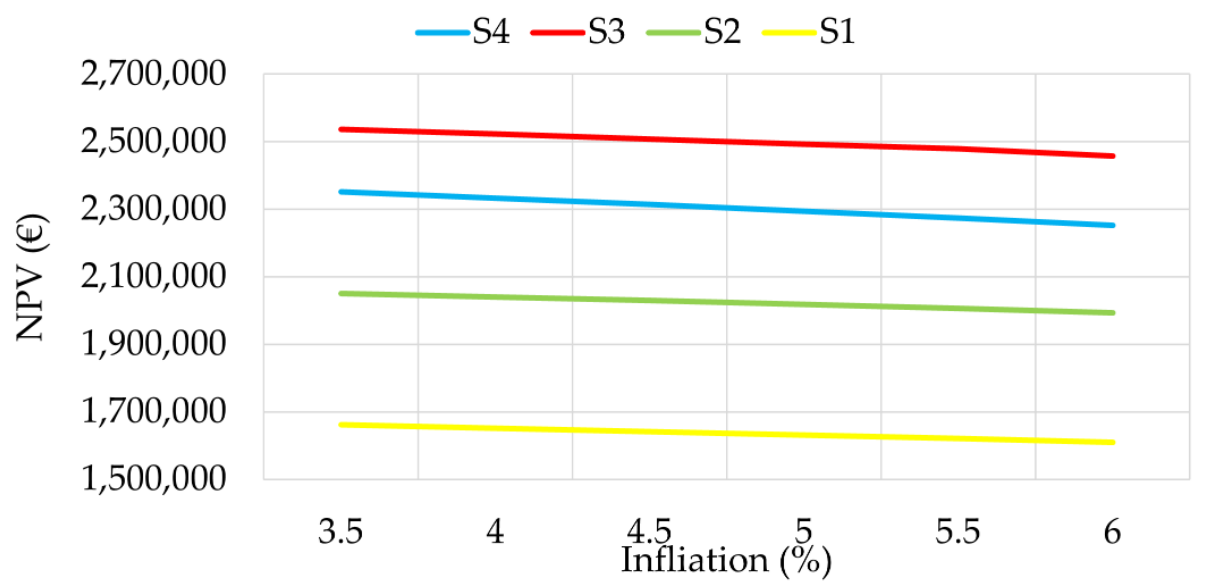

Figure 8. NPV $(E U R)=f(20,0.08$, inf $)$ for each scenario.

Then, the effect of changes in power plant efficiency and losses on the NPV was calculated.

Figures 9-12 show the obtained dependencies. Energy losses at the power plant are caused by the following factors: losses during power generation in the solar modules, losses in the converters, and losses during power transformation. Even though the losses in individual components are insignificant, they can vary in the range of 10 to $20 \%$. At the operating power plant, the losses are about $20 \%$ (data obtained by the authors). 


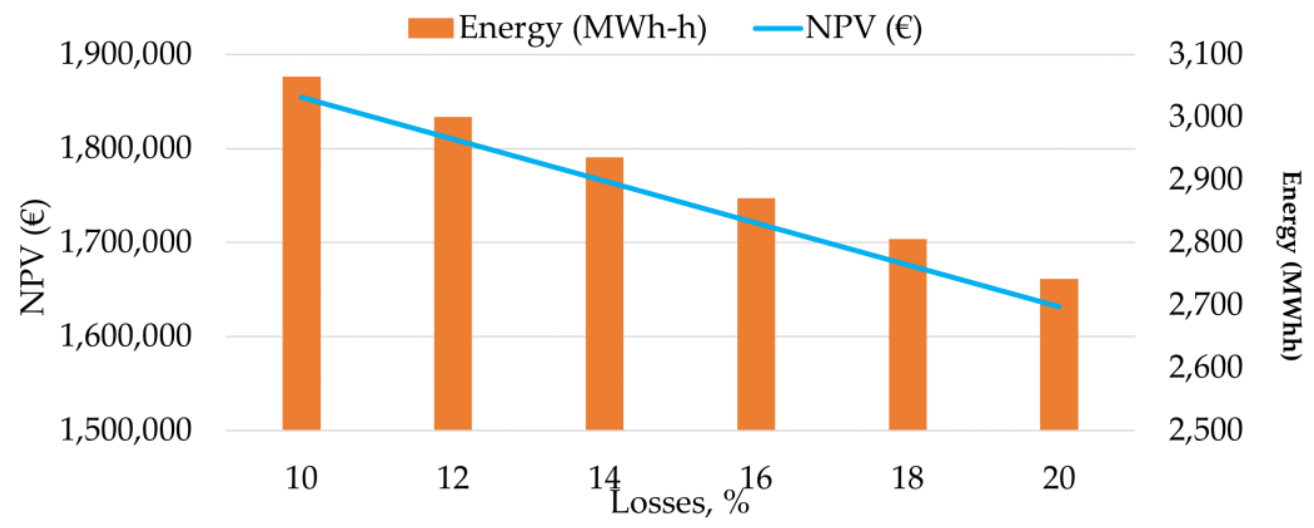

Figure 9. S1 NPV $($ EUR $)=f($ Losses, $0.08,5 \%)$ and Energy $(M W h)=f($ Losses, $0.08,5 \%)$.

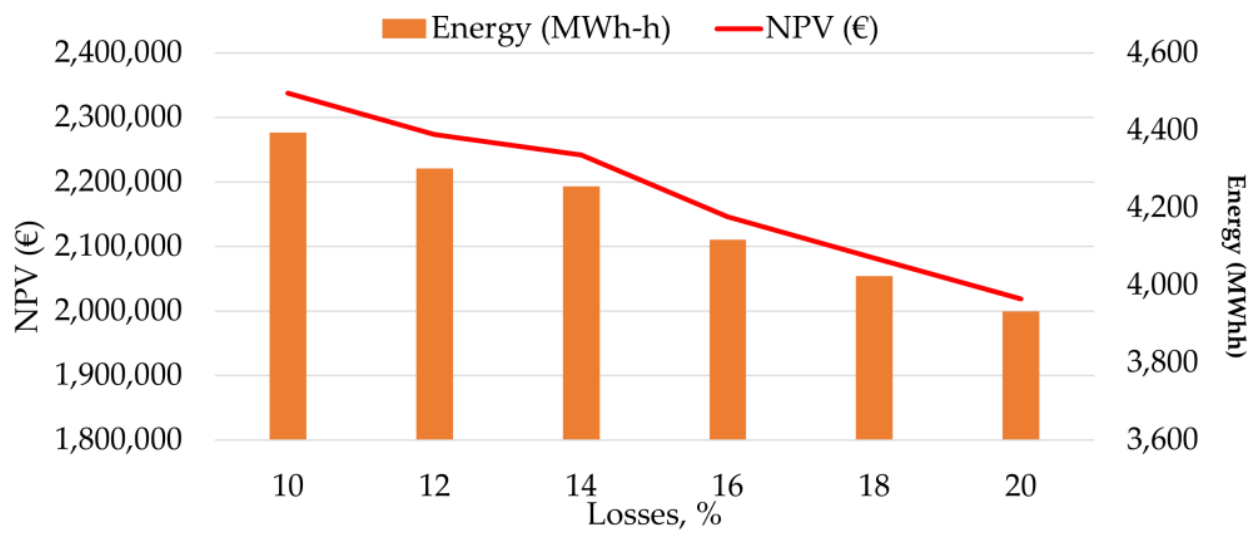

Figure 10. S2 NPV $($ EUR $)=f($ Losses, $0.08,5 \%)$ and Energy $(M W h)=f($ Losses $, 0.08,5 \%)$.

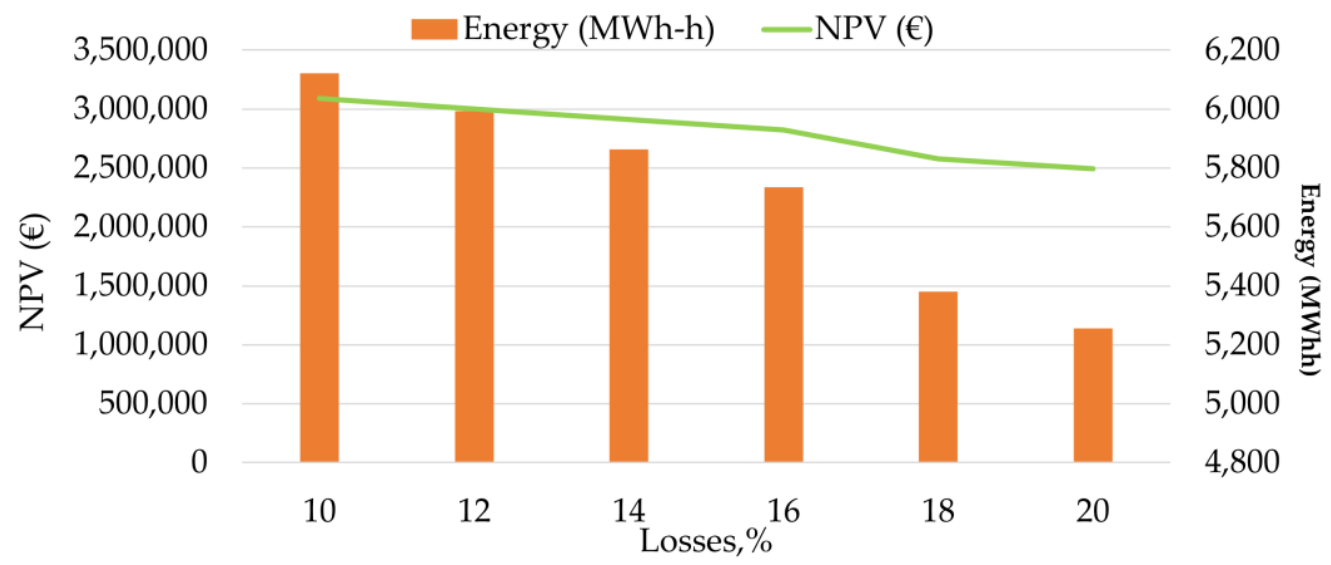

Figure 11. S3 NPV $($ EUR $)=f($ Losses $, 0.08,5 \%)$ and Energy $(M W h)=f($ Losses $, 0.08,5 \%)$.

As can be seen from the obtained dependencies, the largest change in the NPV is observed for S1, S3, and S4. When the losses are reduced by $10 \%$, the NPV increases by $2.49 \%$ of the current value of the NPV (with losses equal to $20 \%$ ). For S1, S2, and S4, the increase in the NPV is $1.36 \%, 1.6 \%$, and $1.86 \%$, respectively.

In the same way, the dynamics of the NPV change was investigated for the cost of a $1 \mathrm{kWh}$ increase from EUR 0.05 to EUR 0.1 (Figure 13). As can be seen from the figure, the highest rate of change in the NPV is characteristic of S4. Nevertheless, the difference in the character of the NPV change for S3 and S4 actually does not change. The least influence of the change of cost on the NPV is observed for S1. 


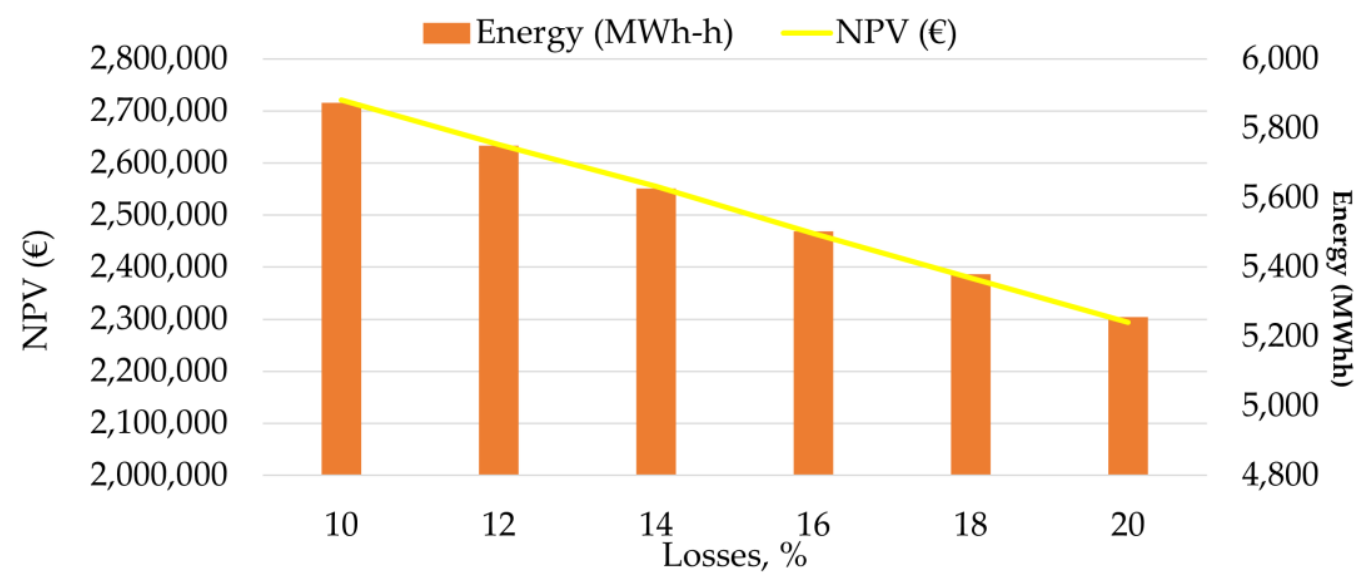

Figure 12. S4 NPV $($ EUR $)=f($ Losses, $0.08,5 \%)$ and Energy $(M W h)=f($ Losses $, 0.08,5 \%)$.

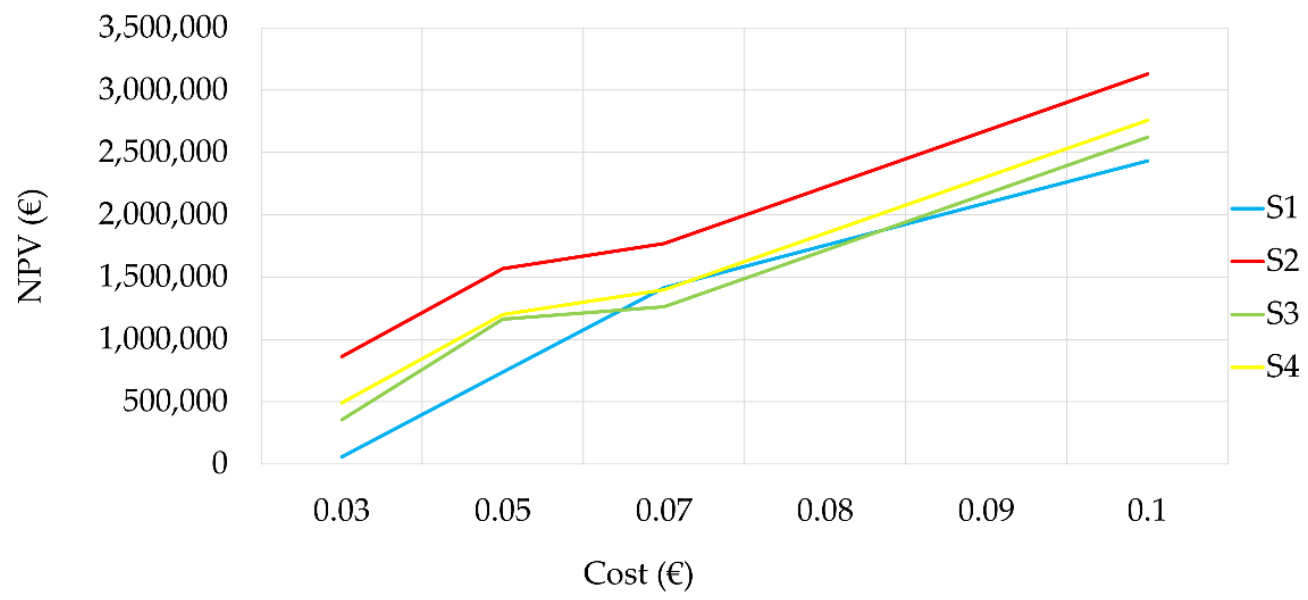

Figure 13. Function graphs for NPV and cost of $1 \mathrm{kWh}$ for all scenarios.

Thus, it was found that out of 4 parameters, the greatest influence on NPV is the value of the cost of $1 \mathrm{kWh}$.

Based on the analysis of the existing technologies, the modern photovoltaic modules, the hardware, and the software for solar tracking systems [55-58] and the object of the research, which was to increase the generation of electric energy by solar power plant $[59,60]$, as well as the economic calculations [61], the methodology of which was given in the previous section, the results of the technical and economic evaluation were obtained (Table 6). Calculation of the internal rate of return IRR, the payback period of the technical project $\mathrm{PRC}$, and the benefit/cost ratio $\mathrm{B} / \mathrm{C}$ were carried out in the software product RETScreen. This program has allowed us to estimate financial feasibility. It should be noted that this calculation was made at a price of EUR 0.08 per $1 \mathrm{kWh}$. This value is taken as the base value due to the fact that in Cuba, the government is responsible for pricing the electricity market, and the price of $1 \mathrm{kWh}$ today is EUR 0.08 .

Table 6. Results of the technical and economic evaluation of modernization scenarios.

\begin{tabular}{ccccc}
\hline Scenario & NPV (EUR) & IRR (\%) & PRC (years) & B/C \\
\hline S0 & - & - & - & - \\
S1 & $2,285,420.27$ & 16.5 & 2.5 & 10.1 \\
S2 & $2,890,403.02$ & 15.7 & 2.7 & 8.8 \\
S3 & $2,489,375.44$ & 13.3 & 3.9 & 5.7 \\
S4 & $2,381,890.34$ & 12.8 & 4.2 & 5.2 \\
\hline
\end{tabular}


Table 6 shows the NPV and IRR values for the four analyzed scenarios (S1-S4). When choosing between scenarios with different IRRs, the project with the highest IRR value is chosen. According to the calculations, the best scenarios to consider are S1 and S2.

It should be noted that the obtained results were confirmed by the calculations performed in the software package RETScreen, a specialized product that allows calculations of the solar power plants from technical and economic points of view.

The results confirm that all the technical solutions are viable, as the NPV is greater than 0 . The profitability of any technical project is determined by the economic GNI. If this indicator is higher than the discount rate set by the financial bank of the region, then we can talk about the profitability of the project. It should be noted that all the indicators given earlier in item 3 were calculated based on an interest rate of $6.5 \%$, a discount rate of $12 \%$, and an inflation rate of $5.5 \%$ (projected inflation growth).

Based on the analysis of the results of the calculations, we can conclude that the four modernization scenarios are profitable but require improvement. For the first technical solution, which consists in replacing all DCM-240-C model solar modules with $16 \%$ efficiency with UZ158MHC340-60 solar modules with 20\% efficiency, the profit-to-cost ratio is 10. This is the best indicator of all the proposed technical solutions. The payback period is 2.5 years.

On the other hand, the implementation of solar monitoring systems for a $2.5 \mathrm{MW}$ power plant in the region of Santiago de Cuba is also a viable proposal (NPV $>0)$ and profitable (IRR $=15 \%>12 \%$ discount rate). The payback period is 3 years, and the profitto-cost ratio is 8.8. Given the technical and economic criteria, it can be argued that the introduction of solar monitoring systems in the Republic of Cuba is technically feasible as the average energy production can increase by $30 \%$ annually. The results of computer simulations performed in previous studies confirm this increase in electrical energy [44]. Figure 14 shows the results of the simulation of a solar power plant with a stationary installation of solar modules and the use of a solar tracking system.

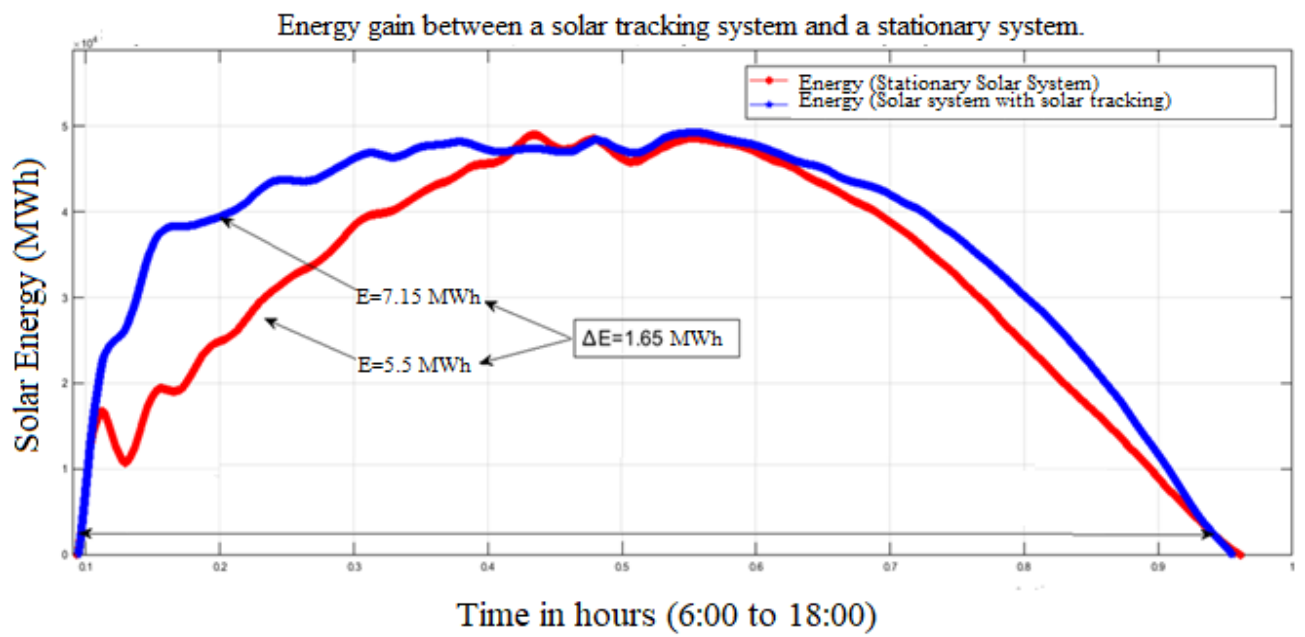

Figure 14. Comparison of the energy generated by a $2.5 \mathrm{MW}$ solar system with a solar tracking system and a stationary solar generator with a slope of 20 degrees.

Thus, based on the theoretical studies, we obtained the results presented in Table 5. It should be noted that based on previous experimental studies and computer simulation, it was revealed that the climatic conditions of the Republic of Cuba are characterized by relatively insignificant fluctuations of ambient temperature, cloudiness, wind speed, and other parameters. Therefore, in calculations with the subsequent modeling, two of the five climatic parameters should be considered-solar radiation and ambient temperature, due to their influence on the operating temperature of the photovoltaic module. This is so because the influence of wind speed on the calculation of energy generation is insignificant in the conditions of the Republic of Cuba. As mentioned earlier, the calculations were 
made taking into account the preservation of the original capacity of the solar power plant $2.5 \mathrm{MW}$.

As can be seen from Table 7, the increase in energy corresponds to an increase in investment in modernization.

Table 7. Results of the conducted economic analysis, taking into account a plant efficiency of $90 \%$ and losses of $10 \%$

\begin{tabular}{cccccc}
\hline Scenario & Cost, E, EUR & $\begin{array}{c}\text { Power Plant } \\
\text { Capacity, P, MW }\end{array}$ & Cost of $\mathbf{1} \mathbf{k W h}, \mathbf{E 1}$ & $\begin{array}{c}\text { Maximum Energy } \\
\text { Generated in Ideal } \\
\text { Conditions W0, GWh }\end{array}$ & $\begin{array}{c}\text { Energy Generated when } \\
\text { 2 Climatic Factors are Taken } \\
\text { into Account, W2, GWh }\end{array}$ \\
\hline S0 & 0 & 2.5 & 0.011 & 3.6 & 3.30 \\
S1 & 831,551 & 2.5 & 0.029 & 3.6 & 3.50 \\
S2 & $1,237,000$ & 2.5 & 0.032 & 4.45 & 4.37 \\
S3 & $1,745,000$ & 2.5 & 0.041 & 4.68 & 4.59 \\
S4 & $1,878,000$ & 2.5 & 0.046 & 4.92 & 4.79 \\
\hline
\end{tabular}

To determine the most effective solution for the conditions of the Republic of Cuba, we plotted the dependencies of the cost of modernization and the amount of energy generated, taking into account two climatic factors (Figure 15). These dependencies are necessary to determine the amount of generated energy in conditions of limited funds. This approach is typical in countries with developing economies and limited resources.

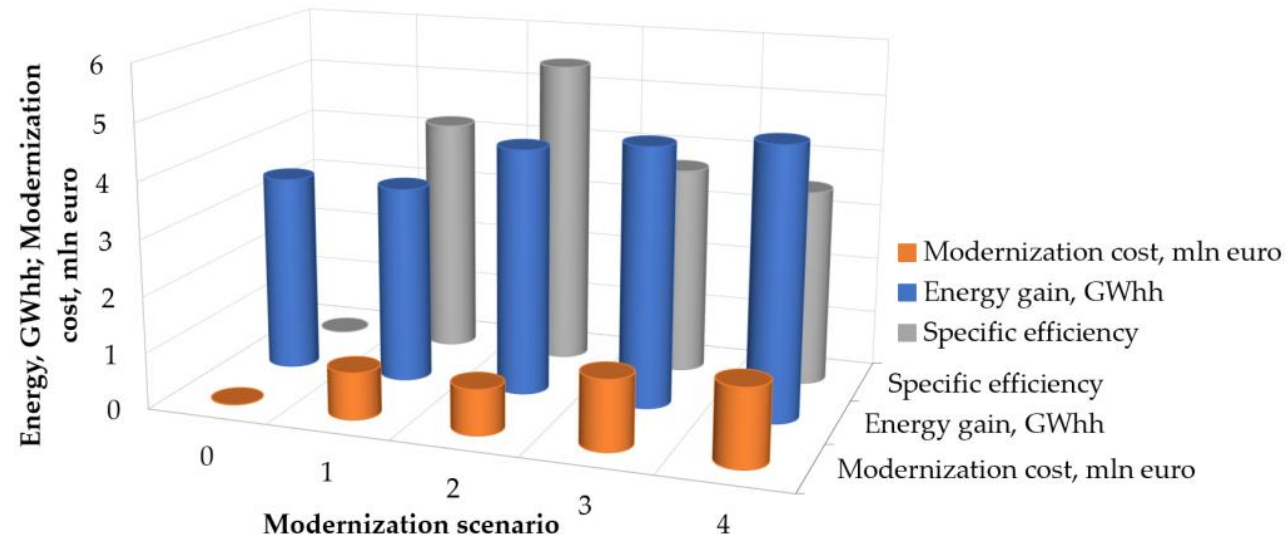

Figure 15. Modernization efficiency.

Analysis of the results shows that the most effective solution, in terms of economic costs and an increase in the energy generated by a solar power plant, is S2 as in this case the energy gain has the highest value and exceeds the average energy gain. However, this is not the most cost-effective modernization option. S2, S3, and S4 show the same dynamics of energy gain, and are less efficient, while $\mathrm{S} 1$ is an ineffective solution as the energy gain is below average, while the cost of upgrading is above average.

Based on the sensitivity analysis, it was obtained that the change in the specific index is sensitive to the change in the energy gain and the lower the investment in modernization, the more sensitive the change. It should be noted that the dependence of the specific index of sensitivity on the energy gain is directly proportional, while the dependence of the same index on investment is hyperbolic, and with investments over EUR 2 million, the index of specific efficiency tends to unity. It was found that all the modernization scenarios are cost-effective when the cost of $1 \mathrm{kWh}$ is more than EUR 0.05 euros as the cost of electricity production of the modernized power plant is between EUR 0.029 and EUR 0.046.

As shown in Figures 9-12, there is an inverse relationship between the NPV and the total PV losses and the cost of producing $1 \mathrm{~kW}$ of PV. 


\subsection{Proposed Algorithm for Choosing Modernization Scenario}

Based on our results, we propose to improve the traditional method of economic evaluation (Figure 7) by taking into account not only the economic parameters of the projects but also the technical parameters of such photovoltaic systems (Figure 16). This approach improves the economic evaluation of solar energy projects. In addition, the proposed improvement is based on future modernization that may be necessary for an existing facility, taking into account the technical indicators that affect the economic parameters for decision making by engineers and technicians.

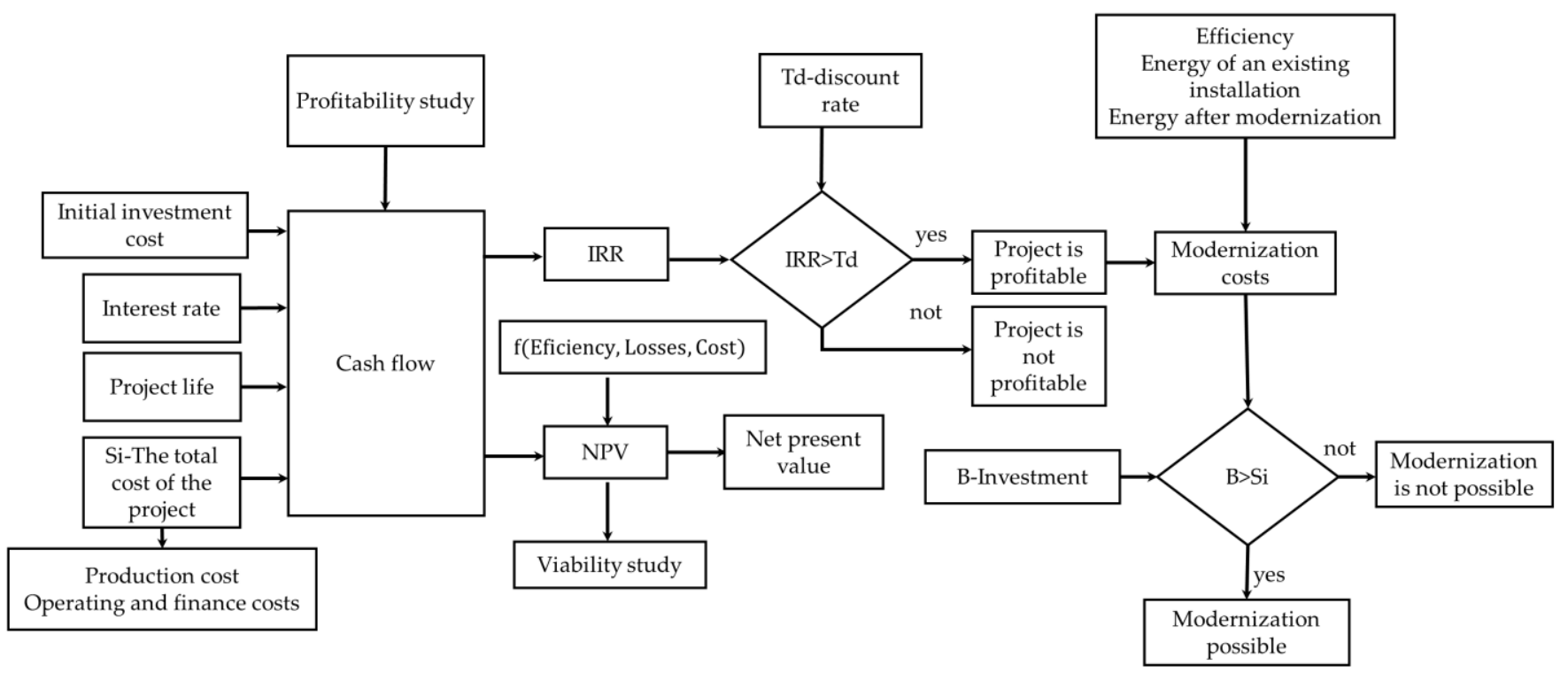

Figure 16. A modified method for evaluation of photovoltaic system profitability.

Based on the results presented above, a simple algorithm for choosing the type of modernization was developed and can be based on the solution of two problems-finding the most effective solution in terms of the efficiency of investing a unit of money and/or finding the most effective solution that provides maximum growth with limited investment power. Figure 17 shows a flow chart of the proposed algorithm.

The algorithm works as follows. First, it is necessary to determine and set the following parameters: the initial capacity of the existing installation and the annual generated energy and the investments in modernization. Then, based on a comprehensive analysis, including analysis of the climatic characteristics of the region and analysis of the modern technologies and technical solutions is carried out, based on which various types of modernization are selected. Then, the number of modernization solutions is determined.

The first calculation in the algorithm is to calculate the cost of each modernization scenario (an example of the calculations is given in the previous section). The calculation is performed until the number of iterations is equal to the number of modernization types. The cost of each scenario is compared to the amount of investment. Those options are excluded where the cost exceeds the amount of investment.

Then, a calculation is made for each type of modernization of the energy gain; it is also compared with the initial energy of the existing power plant. Then, based on the dependencies obtained in the previous section, the most efficient solution in terms of capacity growth and the lowest cost is selected.

The developed algorithm is an easy way for determining the optimal solution for increasing the capacity of the existing power plant, depending on the available funds and the required capacity increase. The simplicity of the algorithm can be confirmed by a comprehensive study at the next stage of its development. 


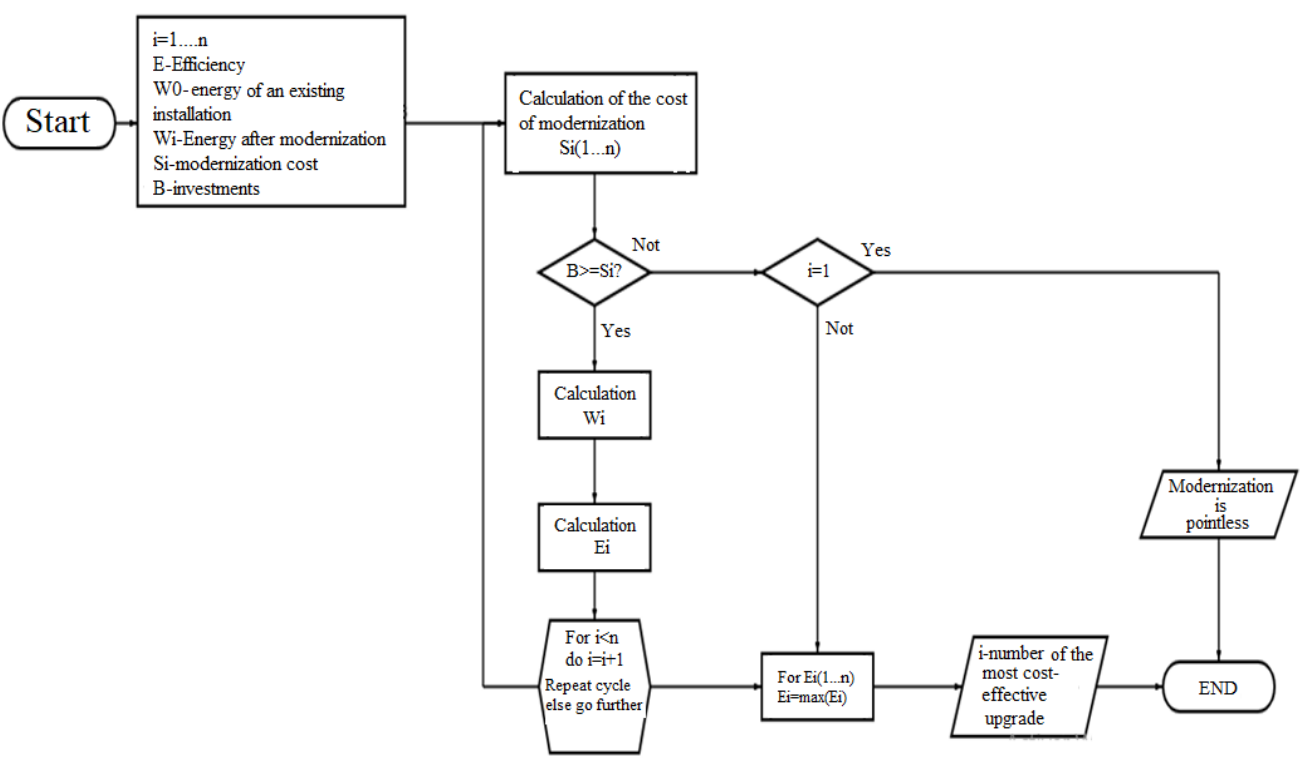

Figure 17. Flowchart of the algorithm for choosing the type of modernization.

\section{Conclusions}

Developing the energy industry and increasing the efficiency of power generation is one of the most important issues for global sustainable development. Improving the efficiency of solar power plants allows us to solve the following problems: increasing the efficiency of natural resources; reducing the cost of power generation; reducing the impact on the environment; promoting the creation of new jobs and infrastructure development; and improving the welfare of mankind. The results of the study presented in the work meet the policy of the Republic of Cuba in the field of renewable energy sources and will increase the share of electricity generation in the total volume of electricity planned for 2030. Increasing the efficiency of the solar power plants contributes to uninterrupted power for the population and an increase in the share of clean electricity in the total volume of electricity generation. It also aimed at the creation of a quality, reliable, sustainable, and flexible infrastructure, including regional and transborder infrastructure, to support economic development and human well-being (target 9.1).

This study presents an algorithm for conducting appropriate solar power plant modernization. Based on the analysis of existing energy efficiency problems, we propose the list of indicators to manage the solar power plant modernization process. In addition, the results can be applied to solar power plants in other Caribbean countries.

Technical indicators include solar module efficiency, power plant efficiency, losses, and solar tracking system availability. Economic indicators include the inflation rate and the cost of $1 \mathrm{kWh}$ of electricity.

The results of the modeling showed that:

1. A change in inflation ranging from $3.5 \%$ to $6 \%$ is equally reflected in the NPV and is about $1.8-2 \%$. The most inflation-sensitive scenario of modernization is S4.

2. The change in generated energy, achieved by reducing power losses at a solar power plant, has a more diverse character and ranges from $1.3 \%$ to $2.5 \%$ depending on the type of retrofit. In addition, it should be noted that the most reliable type of modernization is S3. This can be explained by the fact that the partial replacement of equipment negatively impacts electricity generation. Besides, as was revealed in the study, the S3 and S4 modernizations are the most energy efficient.

3. The NPV is directly proportional to the price of $1 \mathrm{kWh}$. For the chosen type of modernization (S2), an increase in cost by $20 \%$ leads to an increase in the NPV of $50 \%$ on average. 
4. It was determined that electricity production in the Republic of Cuba will be profitable only if the price per $\mathrm{kWh}$ is at least EUR 0.036, EUR 0.04, EUR 0.051, and EUR 0.057 for the S1-S4 retrofits, respectively.

However, further research is required as this work did not take into account the possible negative impact of direct-conversion solar power plants on the microclimate of the region. It is assumed that an increase in the area of the panels contributes to the local heating of the air around the modules. Therefore, future work will also aim at conducting a series of experiments that will answer the question of the relationship between the increase in the area occupied by the power plant and the increase in energy, as well as the impact of modernization on the environment in the region. The results of these studies may make adjustments not only in the methodology for selecting the modernization method (introducing another input value - the impact on the environment) but also subsequently in the operation of the algorithm.

The second line of further research is the application of methods for determining the significant climatic parameters of electricity generation and the calculation of the specific power of modernization for other climatic zones.

In conclusion, it should be noted that the role of subsidies was not considered in this work as the purpose of the work was to find the most effective way to obtain maximum power at a minimum cost. The role of the state in this project is reflected only in the reduced rate on loans.

Author Contributions: Conceptualization, E.I., D.G., Y.S. and P.T.; methodology, E.I., D.G. and Y.S.; validation, E.I. and D.G..; formal analysis, E.I. and D.G.; investigation, E.I. and D.G.; resources, E.I., D.G., Y.S. and P.T.; writing-original draft preparation, E.I., D.G. and P.T.; writing-review and editing, E.I., Y.S. and P.T.; visualization, E.I. and D.G. All authors have read and agreed to the published version of the manuscript.

Funding: This research received no external funding.

Institutional Review Board Statement: Not applicable.

Informed Consent Statement: Not applicable.

Data Availability Statement: Not applicable.

Conflicts of Interest: The authors declare no conflict of interest.

\section{Appendix A}

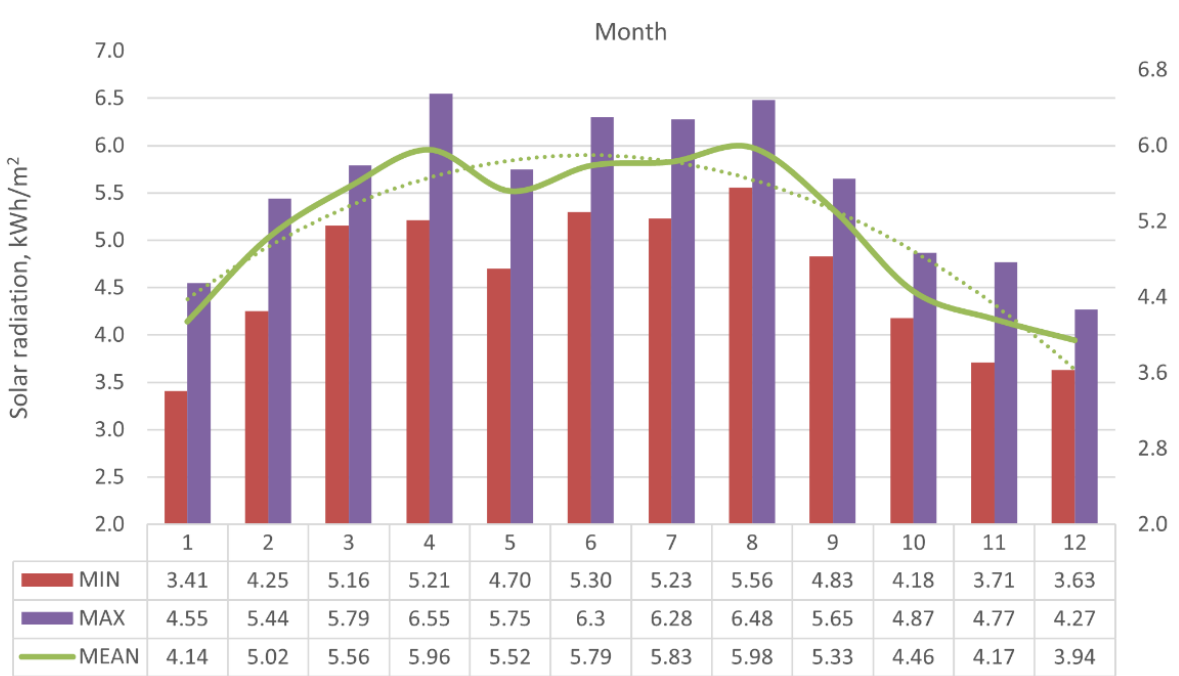

Figure A1. Change in solar radiation at the installation site of a solar power plant during the year. 


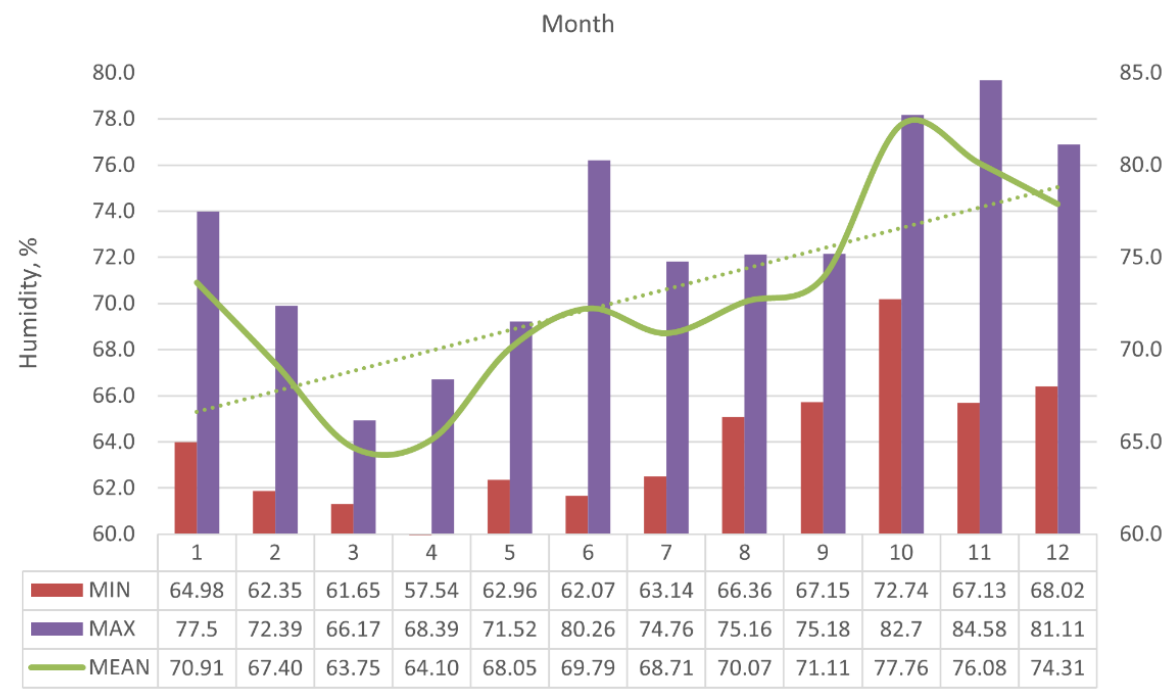

Figure A2. Change in humidity at the installation site of a solar power plant during the year.

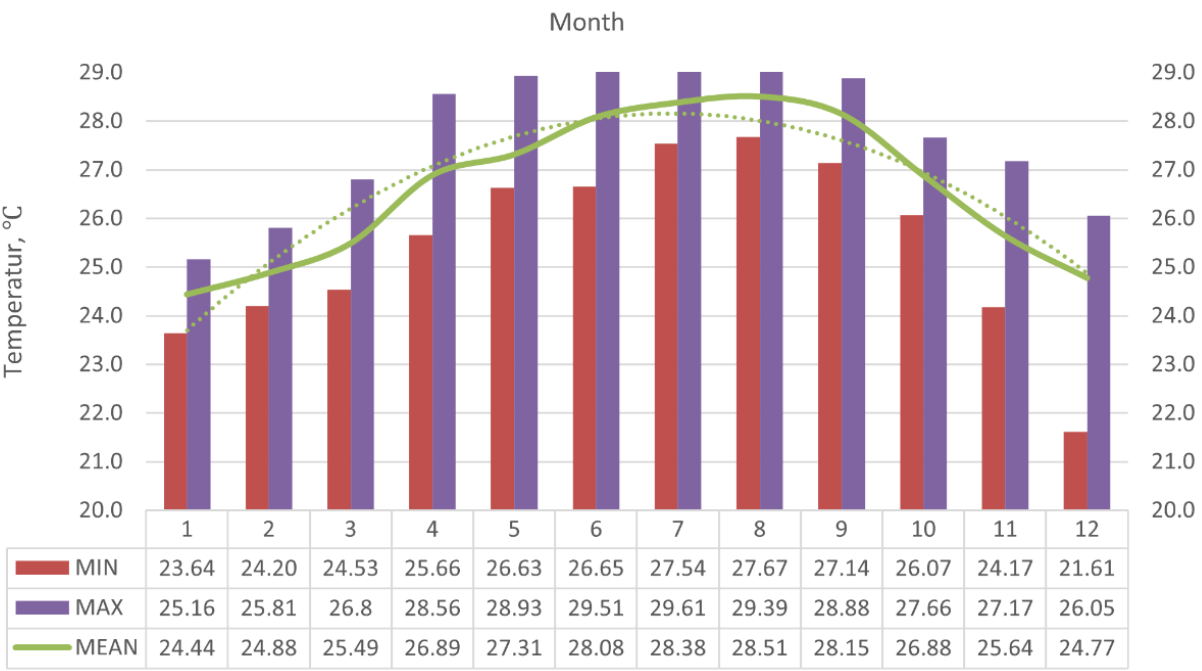

Figure A3. Change in temperature at the installation site of a solar power plant during the year.

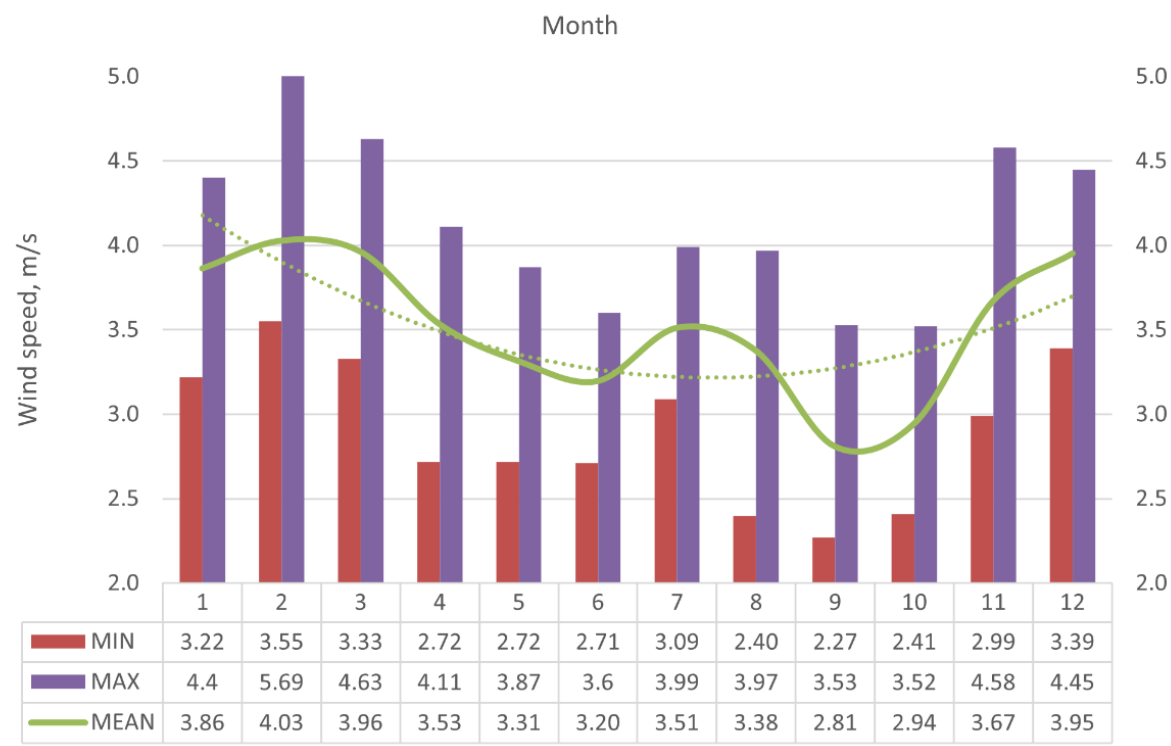

Figure A4. Change in wind speed at the installation site of a solar power plant during the year. 


\section{References}

1. Tcvetkov, P. Climate Policy Imbalance in the Energy Sector: Time to Focus on the Value of $\mathrm{CO}_{2}$ Utilization. Energies 2021, $14,411$. [CrossRef]

2. Bataev, A.; Potyarkin, V.; Glushkova, A.; Samorukov, D. Assessment of development effectiveness of solar energy in Russia. E3S Web Conf. 2020, 221, 03002. [CrossRef]

3. Deng, X.; Ge, J. Global wind power development leads to high demand for neodymium praseodymium (NdPr): A scenario analysis based on market and technology development from 2019 to 2040. J. Clean. Prod. 2020, 277, 123299. [CrossRef]

4. Poliakov, N.; Vorobev, K.; Demidova, G.; Rassolkin, A.; Ramensky, D. Case Study of Supplementary PMSM for Low-Speed Wind Turbine. In Proceedings of the 2021 18th International Scientific Technical Conference Alternating Current Electric Drives (ACED), Ekaterinburg, Russia, 24-27 May 2021.

5. Burić, M.; Grgurić, S.; Mikulčić, H.; Wang, X. A numerical investigation of tidal current energy resource potential in a sea strait. Energy 2021, 234, 121241. [CrossRef]

6. Boguslavsky, E.I. World experience of geothermal engineering. Gorn. Zhurnal 2016, 1, 19-23. [CrossRef]

7. Yang, X.; Liu, Y.; Thrän, D.; Bezama, A.; Wang, M. Effects of the German Renewable Energy Sources Act and environmental, social and economic factors on biogas plant adoption and agricultural land-use change. Energy Sustain. Soc. 2021, 11, 6. [CrossRef]

8. Kovshov, S.V.; Skamyin, A. Treatment of agricultural wastes with biogas-vermitechnology. Environ. Earth Sci. 2017, 76, 660. [CrossRef]

9. Syahputra, R.; Soesanti, I. Renewable energy systems based on micro-hydro and solar photovoltaic for rural areas: A case study in Yogyakarta, Indonesia. Energy Rep. 2021, 7, 472-490. [CrossRef]

10. Belsky, A.A.; Skamyin, A.N.; Vasilkov, O.S. The Use of Hybrid Energy Storage Devices for Balancing the Electricity Load Profile of Enterprises. Energ. Proc. CIS High. Educ. Inst. Power Eng. Assoc. 2020, 63, 212-222. [CrossRef]

11. Zhukovskiy, Y.L.; Lavrik, A.Y.; Buldysko, A.D. Energy demand side management in stand-alone power supply system with renewable energy sources. J. Phys. Conf. Ser. 2021, 1753, 012059. [CrossRef]

12. Bardanov, A.I.; Vasilkov, O.S.; Pudkova, T.V. Modeling the process of redistributing power consumption using energy storage system with various configurations to align the electrical loads schedule. J. Phys. Conf. Ser. 2021, 1753, 012013. [CrossRef]

13. Capizzi, G.; Sciuto, G.L.; Napoli, C.; Tramontana, E. Advanced and Adaptive Dispatch for Smart Grids by Means of Predictive Models. IEEE Trans. Smart Grid 2017, 9, 6684-6691. [CrossRef]

14. Rassõlkin, A.; Sell, R.; Leier, M. Development case study of the first estonian self-driving car, iseauto. Electr. Control. Commun. Eng. 2018, 14, 81-88. [CrossRef]

15. Abramovich, B.N.; Veprikov, A.A.; Sychev, Y.A.; Lyakh, D.A. Use of active power transducers in industrial DC power systems supplying electrolysis cells. Tsvetnye Met. 2020, 2, 95-100. [CrossRef]

16. Boikov, A.V.; Savelev, R.V.; Payor, V.A.; Vasileva, N.V. DEM calibration approach: Orthogonal experiment. J. Phys. Conf. Ser. 2019, 1210, 012025. [CrossRef]

17. Van de Ven, D.-J.; Capellan-Peréz, I.; Arto, I.; Patel, P.; Gonzalez-Eguino, M. The potential land requirements and related land-use change emissions of solar energy. Sci. Rep. 2021, 11, 2907. [CrossRef] [PubMed]

18. Pashkevich, M.A.; Bech, J.; Matveeva, V.A.; Alekseenko, A.V. Biogeochemical as-assessment of soils and plants in industrial, residential and recreational areas of Saint Petersburg. J. Min. Inst. 2020, 241, 125-130. [CrossRef]

19. Çoban, V. Solar energy plant project selection with AHP decision-making method based on hesitant fuzzy linguistic evaluation. Complex. Intell. Syst. 2020, 6, 507-529. [CrossRef]

20. Kiene, S.; Linkevics, O. Simplified Model for Evaluation of Hydropower Plant Conversion into Pumped Storage Hydropower Plant. Latv. J. Phys. Tech. Sci. 2021, 58, 108-120. [CrossRef]

21. Shen, L.; Zhang, G. Optimization Design of Civil Engineering Construction Schedule Based on Genetic Algorithm. J. Phys. Conf. Ser. 2021, 1852. [CrossRef]

22. Khokhlov, D.A.; Khokhlova, D.A.; Sterkhov, K.V.; Zaichenko, M.N.; Likholetova, V.S. The Economic Effect Determination for Combined Cycle Power Plant with Pressurized Heat Recovery Steam Generator. In Proceedings of the 3rd 2021 International Youth Conference on Radio Electronics, Electrical and Power Engineering (REEPE), Moscow, Russia, 11-13 March 2021.

23. Naval, N.; Sánchez, R.; Yusta, J.M. A virtual power plant optimal dispatch model with large and small-scale distributed renewable generation. Renew. Energy 2020, 151, 57-69. [CrossRef]

24. Dolara, A. Energy comparison of seven MPPT techniques for PV systems. J. Electromagn. Anal. Appl. 2009, 1, 152-162. [CrossRef]

25. Ohunakin, O.S.; Saracoglu, B.O. A comparative study of selected multi-criteria decision-making methodologies for location selection of very large concentrated solar power plants in Nigeria. Afr. J. Sci. Technol. Innov. Dev. 2017, 10, 551-567. [CrossRef]

26. Azadeh, A.; Sheikhalishahi, M.; Asadzadeh, S. A flexible neural network-fuzzy data envelopment analysis approach for location optimization of solar plants with uncertainty and complexity. Renew. Energy 2011, 36, 3394-3401. [CrossRef]

27. Demenkova, T.A.; Korzhova, O.A.; Phinenko, A.A. Modelling of algorithms for solar panels control systems. In Proceedings of the XIIth International Symposium «Intelligent Systems», INTELS16, Moscow, Russia, 5-7 October 2016.

28. Rodríguez-Ossorio, J.-R.; González-Martínez, A.; de Simón-Martín, M.; Diez-Suárez, A.-M.; Colmenar-Santos, A.; Rosales-Asensio, E. «Levelized cost of electricity for the deployment of solar photovoltaic plants: The region of León (Spain) as case study». Energy Rep. 2021, 7, 199-203. [CrossRef] 
29. Wang, T.-C.; Tsai, S.-Y. Solar Panel Supplier Selection for the Photovoltaic System Design by Using Fuzzy Multi-Criteria Decision Making (MCDM) Approaches. Energies 2018, 11, 1989. [CrossRef]

30. Nikishin, A.J.; Kharitonov, M.S. Modernization of marine ports electrical power supply systems in the framework of zero-emission strategy. IOP Conf. Ser. Earth Environ. Sci. 2021, 689, 012018. [CrossRef]

31. GreenPort 2018 IMO Sets First Industry Wide Emissions Strategy. Available online: https://www.greenport.com/news101 /Regulation-and-Policy/imo-sets-firstindustry-wideemissions-strategy (accessed on 21 November 2021).

32. Afgan, N.H.; Jovanović, M.; Carvalho, M.G. Sustainability Assessment of Solar Energy Systems. In Proceedings of the International Solar Energy Conference, Portland, OR, USA, 11-14 July 2004; pp. 205-215.

33. Iakovleva, E.; Guerra, D.D.; Shklyarskiy, A. Alternative Measures to Reduce Carbon Dioxide Emissions in the Republic of Cuba. J. Ecol. Eng. 2020, 21, 55-60. [CrossRef]

34. Report GMSP BV 'Cuba Sustainable Energy Forum 2018'-Reference: MAK17CU02A. Available online: https://www.rvo.nl/ sites/default/files/2018/06/Cuba-Sustainable-Energy-Forum-2018-Final-report_0.pdf (accessed on 1 December 2021).

35. IRENA (2020), Renewable Energy Statistics 2020 the International Renewable Energy Agency, Abu Dhabi. Available online: https: / / www.irena.org/-/media/Files/IRENA/Agency/Publication/2020/Jul/IRENA_Renewable_Energy_Statistics_2020.pdf (accessed on 1 December 2021).

36. Bazhin, V.Y.; Nikolaev, A.N.; Turro, A.B. New methods of processing of Cuban nickel ores and technogenic slimes. IOP Conf. Ser. Mater. Sci. Eng. 2020, 862, 1177-1181. [CrossRef]

37. Palyanova, N.V.; Chubukova, S.; Zadkov, D.A. Legal framework for the sustainable economic and ecological development in the coal industry in Russia. Eurasian Min. 2017, 1, 3-5. [CrossRef]

38. Malyshkov, G.; Sinkov, L.S.; Nikolaichuk, L. Analysis of economic evaluation methods of environmental damage at calculation of production efficiency in mining industry. Int. J. Appl. Eng. Res. 2017, 12, 2551-2554.

39. Kozioł, J.; Mendecka, B. Evaluation of Economic, Energy-environmental and Sociological Effects of Substituting Non-renewable Energy with Renewable Energy Sources. J. Sustain. Dev. Energy Water Environ. Syst. 2015, 3, 333-343. [CrossRef]

40. Mirtchev, A.; Mouselinos, T.; Syrigos, S.; Tatakis, E. Behavioral Analysis of Potential Induced Degradation on Photovoltaic Cells, Regeneration and Artificial Creation. Energies 2021, 14, 3899. [CrossRef]

41. Hasan, A.; Alkahtani, A.A.; Shahahmadi, S.; Alam, M.N.E.; Islam, M.; Amin, N. Delamination-and Electromigration-Related Failures in Solar Panels-A Review. Sustainability 2021, 13, 6882. [CrossRef]

42. López-González, A.; Domenech, B.; Ferrer-Martí, L. Sustainability Evaluation of Rural Electrification in Cuba: From Fossil Fuels to Modular Photovoltaic Systems: Case Studies from Sancti Spiritus Province. Energies 2021, 14, 2480. [CrossRef]

43. Chiou, J.-M.; Yang, Y.-F.; Chen, Y.-T. Multivariate functional principal component analysis: A normalization approach. Stat. Sin. 2014, 24, 1571-1596. [CrossRef]

44. Iakovleva, E.V.; Guerra, D.D. Improving the efficiency of the use of photovoltaic stations in the republic of Cuba. J. Phys. Conf. Ser. 2021, 1753, 012056. [CrossRef]

45. Peng, Z.; Herfatmanesh, M.R.; Liu, Y. Cooled solar PV panels for output energy efficiency optimisation. Energy Convers. Manag. 2017, 150, 949-955. [CrossRef]

46. Glazev, M.; Bazhin, V. Environmental technologies in the production of metallurgical silicon. In Scientific and Practical Studies of Raw Material Proceedings of the Russian-German Raw Materials Dialogue: A Collection of Young Scientists Papers and Discussion; CRC: Boca Raton, FL, USA, 2019; pp. 114-119.

47. Al-Najideen, M.I.; AlRwashdeh, S.S. Design of a solar photovoltaic system to cover the electricity demand for the faculty of Engineering- Mu'tah University in Jordan. Resour. Technol. 2017, 3, 440-445. [CrossRef]

48. ENF Solar. Available online: https:/ / es.enfsolar.com/pv/panel/3 (accessed on 15 April 2021).

49. Abramovich, B.N. Uninterruptible power supply system for mining industry enterprises. J. Min. Inst. 2018, 229, 31-40.

50. Breyer, C.; Schmid, J. Population Density and Area Weighted Solar Irradiation: Global Overview on Solar Resource Conditions for Fixed Tilted, 1-Axis and 2-Axes PV Systems. In Proceedings of the 25th European Photovoltaic Solar Energy Conference and Exhibition/5th World Conference on Photovoltaic Energy Conversion, Valencia, Spain, 6-10 September 2010. [CrossRef]

51. Ministerio de Energía y Minas. Available online: https://www.minem.gob.cu/aviso/nueva-tarifa-electrica-2021 (accessed on 22 May 2021).

52. Bulgakov, A.U. Evaluation of the Efficiency of Using Solar Panels in Siberia. Master's Thesis, National Research Tomsk Polytechnical University, Tomsk, Russia, 2016.

53. Rosabal, S.B.; Castillo, A.M.; Santiesteban, L.A.Q.; Martínez, Y.F. SICODI, a system proposal for management of information from meetings and its use en the Cubapetroleo Union. ACIMED 2011, 22, 362-370.

54. Minakov, V.F.; Lobanov, O.S.; Minakova, T.E.; Makarchuk, T.A.; Kostin, V.N. The law of diminishing marginal productivity in the model of pure discounted income of innovations. Int. J. Econ. Res. 2017, 14, 435-441.

55. Minakov, V.F.; Minakova, T.E.; Lobanov, O.S.; Kostin, V.N.; Makarchuk, T.A. The expansion of time series innovations in a series of sigmoid. Int. J. Appl. Bus. Econ. Res. 2017, 15, 311-319.

56. Khatkov, V.Y.; Boyarko, G.Y. Administrative methods of import substitution management of deficient types of mineral raw materials. J. Min. Inst. 2018, 234, 683-692. [CrossRef]

57. Ali, M.I.M.; Husni, M.H. Efficiency of solar cells for UAV. Int. J. Inov. Technol. Explor. Eng. 2019, 8, 575-577. 
58. Alonso-Montesinos, J.; Martínez, F.R.; Polo, J.; Martín-Chivelet, N.; Batlles, F.J. Economic Effect of Dust Particles on Photovoltaic Plant Production. Energies 2020, 13, 6376. [CrossRef]

59. Barbón, A.; Bayón-Cueli, C.; Bayón, L.; Ayuso, P.F. Influence of solar tracking error on the performance of a small-scale linear Fresnel reflector. Renew. Energy 2020, 162, 43-54. [CrossRef]

60. Ngoc, T.N.; Phung, Q.N.; Tung, L.N.; Sanseverino, E.R.; Romano, P.; Viola, F. Increasing efficiency of photovoltaic systems under non-homogeneous solar irradiation using improved Dynamic Programming methods. Sol. Energy 2017, 150, 325-334. [CrossRef]

61. Juhász, L. Net Present Value versus Internal Rate of Return. Econ. Sociol. 2011, 4, 46-53. [CrossRef] 